\title{
A GEOMORFOLOGIA DA SERRA DO ESPINHAÇO EM MINAS GERAIS E DE SUAS MARGENS
}

\begin{abstract}
Allaoua Saadi (*)
ABSTRACT

The geomorphological evolution of the Serra do Espinhaço is discussed based on: a) a critical analysis of previous papers about the geomorphology of the range, b) new interpretation based on own field data, c) regional interpretation, considering informations about the evolution of adjacent areas west and east of the range (São Francisco River, Doce River and Jeqitinhonha-Araçuaí Rivers Basins). The global context is presented as a synthetical characterization of the main geological conditions, regional physiography and drainage system organization and anomalies.

The regional geomorphological organization is rigid controlled by the geology: a) the shape of the range reproduce the original collisional arc developed during the proterozoic orogeny, $b$ ) the existence of two strongly diferenciated plateaux (Planalto Meridional and Planalto Setentrional) reflect the litho-structural contrast between the southern and northern parts of the range, c) the morphology expresses the association between lithological resistance to erosion and the tectonic organization in all scales.

The morphology of the higher portions of the plateaux is characterized by relicts of two tertiary planation surfaces. They are probably peneplains resulting from erosion under tropical humid climatic conditions. During the Pleistocene, the valleys recorded the formation of several stepped terraces. the spacial variation on its dislevelments reflects the intensity of crustal uplifts and the position of the streams in the drainage system hierarchy. The hillsides were, during the Upper Pleistocene, covered by two fine colluvial layers. In both cases, the cenozoic sediments register evidences of humid and hot paleoclimatic conditions.

The Serra do Espinhaço acquired its present main physiography after the Miocene, which was characterized by tectonic stability. During the Pliocene, a strong compressional tectonic event reactivated the main precambrian thrust faults and detachment planes. As a consequence, the high scarp related to the west thrust front was enhanced together with a eastward tilting of the plateaux. At the same time, in the Planalto Setentrional, several valley heads of the São Francisco drainage basin were deviated and captured by the Jequitinhonha Basin drainage system. In the Planalto Meridional, the geological conditions (porous lithology and anticline structure) favoured the capture of streams by the São Francisco Basin drainage system.

As a consequence of the compressional forces that uplifted the range, an extensional stress field developed in the eastern border, generating grabens structures where the main rivers installed its valleys. The neotectonic activity is also recorded in several parts of the range and adjacent areas by normal, reverse and strike-slip faults in pleistocenic alluvial and colluvial deposits. Fault planes data analysis indicates a general NW-SE compressional stress field that remains up to the present time, as confirmed by results of seismological data.
\end{abstract}

\section{INTRODUÇÃO}

A Serra do Espinhaço — grande divisor hidrográfico interposto entre as bacias do centro-leste brasileiro e a do rio São Francisco - constitui, em Minas Gerais, um conjunto de terras altas, com forma de bumerangue de direção geral norte-sul e convexidade orientada para oeste. A denominação "serra" esconde, no entanto, uma realidade fisiográfica que seria melhor definida pelo termo "planalto".

Apesar dessa geometria encurvada resultar de um mesmo processo geotectônico, as duas asas correspondem a dois compartimentos de planaltos, nitidamente diferenciados do ponto de vista litoestrutural e morfológico. Os planaltos meridional e setentrional, com direções gerais, SSE-NNW e SSWNNE respectivamente, são separados por uma zona deprimida alongada na direção SE-NW, passando por Couto de Magalhães, pouco a norte de Diamantina (Fig. 1).
A descoberta de recursos minerais (principalmente ouro e diamante) despertou, bem cedo, um forte interesse para o estudo da geologia da Serra do Espinhaço, devidamente desenvolvido, incentivado e apoiado, a partir dos anos 70, pelo Centro de Geologia Eschwege. Tal dedicação não foi, no entanto, dispensada à investigação de sua história geomorfológica. Os trabalhos que tratam diretamente de partes desta serra, são poucos e caracterizados por enfoques muito variados.

Ao assumir a tarefa de elaborar um trabalho sobre a geomorfologia do conjunto da Serra do Espinhaço mineira, objetiva-se, em primeiro lugar, retratar o estado do conhecimento sobre o assunto e, em segundo lugar, propor uma interpretação da gênese do relevo que considere os papéis respectivos dos fatores climático e tectônico.

A escala da análise e o posicionamento da serra no contexto geológico-geomorfológico do centro-leste brasileiro geram a necessidade de estender a 


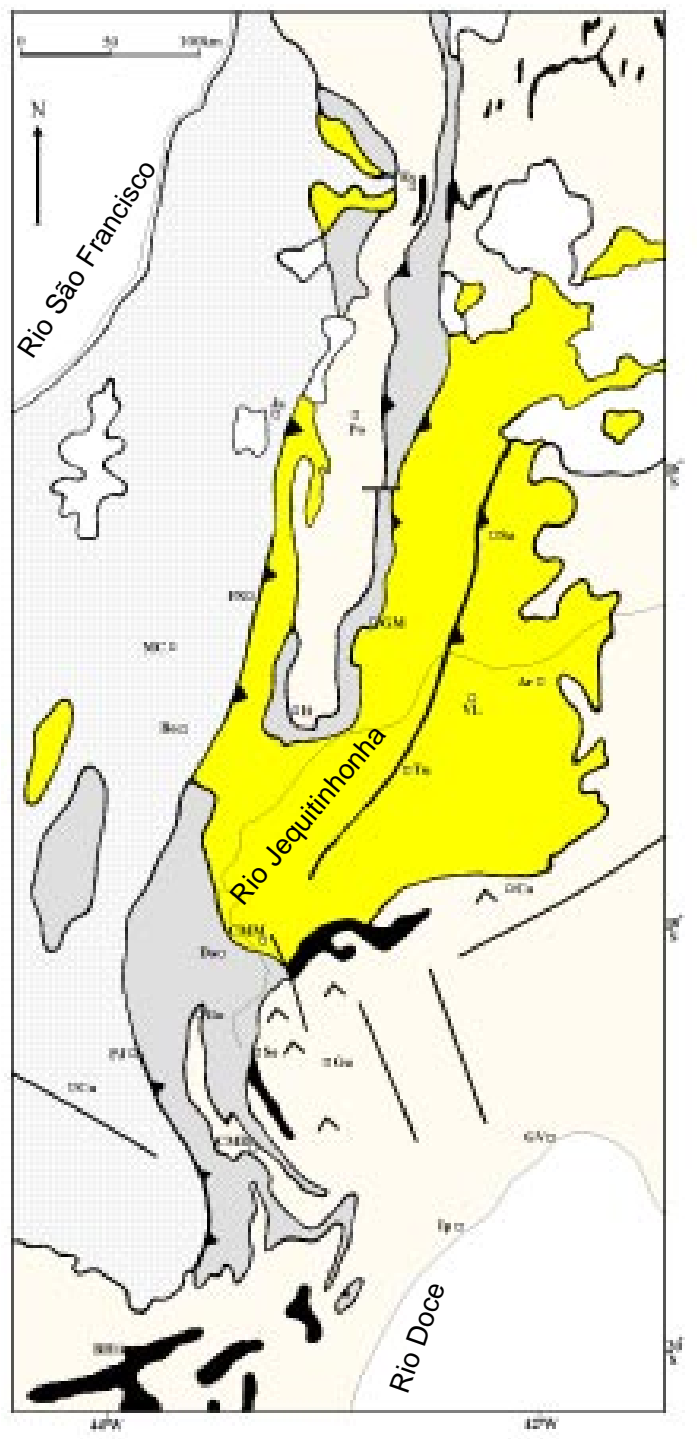

investigação às regiões marginais, buscando-se dados complementares para apoiar a interpretação em escala regional. Estas informações encontram-se na margem direita da bacia do rio São Francisco, a oeste, e nas bacias dos rios Doce e Jequitinhonha/Araçuaí, a leste.

\section{AS CONDIÇÕES GEOLÓGICAS BÁSICAS}

O condicionamento do relevo da Serra do Espinhaço por características geológicas peculiares ao orógeno homônimo, é o fato mais consensual entre os estudiosos da geomorfologia da região. A falta de consenso encontra-se, no entanto, entre os próprios profissionais da geologia local. Por esta razão e pelo fato deste trabalho encontrar-se publicado junto a um debate completo sobre esta geologia, limitar-se-á a uma descrição, das mais sucintas, das características básicas que permitem entender a inserção da formação do relevo dentro dos contextos litológico e estrutural do Orógeno Espinhaço.

Para isto, baseou-se em algumas das publicações mais recentes, considerando sobretudo o seu nível de

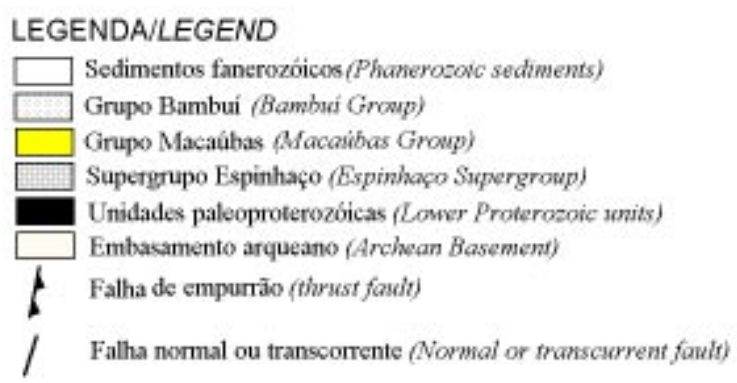

Figura 1: Esboço geológico da Serra do Espinhaço em Minas Gerais e suas margens.

Figure 1: Geological sketch - map of the Serra do Espinhaço and adjacent areas.

Ar: Araçuaí; BH: Belo Horizonte; Bo: Bocaiuva;

Ca: Capelinha; CMD: Conceição do Mato Dentro;

CMM: Couto de Magalhães de Minas; Cu: Curvelo;

Da: Diamantina; Es: Espinosa; Fs: Francisco Sá;

GM: Grão Mogol; Go: Gouveia; Gu: Guanhães; GV: Governador Valadares; Ip: Ipatinga;

It: Itacambira; Ja: Januária; MC: Montes Claros;

PJ: Presidente Juscelino: Po: Porteirinha; Sa: Salinas;

Se: Serro; Tu: Turmalina; VL: Virgem da Lapa.

abrangência e o fato de proporem modelos globais que resumem as informações necessárias.

\section{Evolução geotectônica précambriana}

No que interessa aos propósitos deste trabalho, a Serra do Espinhaço Meridional constitui o resultado da seguinte sequência de eventos geotectônicos (Almeida Abreu \& Pflug 1994): a) rifteamento em torno de 1.752Ma. (final do Paleoproterozóico), dando início à formação de uma bacia onde se acumularam mais de $5.000 \mathrm{~m}$ de sedimentos predominantemente areníticos do Supergrupo Espinhaço; b) fechamento da bacia por esforços compressivos com transporte de $\mathrm{E}$ para W, gerando o Orógeno Espinhaço em torno de $1.250 \mathrm{Ma}$ (Mesoproterozóico); c) durante os 250Ma seguintes, processou-se a sedimentação do Grupo Macaúbas, parcialmente glaciogênica e mais desenvolvida na parte setentrional; d) em torno de $900 \mathrm{Ma}$ (Neoproterozóico), um evento distensivo foi responsável por intenso magmatismo basáltico e a subsequente subsidência do Cráton do São Francisco, que permitiu a formação da bacia que acolheu os sedimentos pelítico-carbonáticos do Grupo Bambuí; e) ao final do Neoproterozóico, o amalgamento do Supercontinente Gondwana induz uma reativação das estruturas nucleadas anteriormente, resultando em empurrões de $\mathrm{E}$ para $\mathrm{W}$, impondo a superposição das sequências do Supergrupo Espinhaço às dos grupos Macaúbas e Bambuí.

\section{Estruturas principais e litologias associadas}

Como resultado desta complexa evolução geotectônica proterozóica, herdou-se o seguinte quadro lito-estrutural (Fig. 1) que passará a influenciar a evolução geomorfológica da região:

- existência de uma unidade geo-estrutural de 
direção meridiana, instalada na borda leste do Cráton do São Francisco, sobre um embasamento arqueano (Complexo Basal), composto por granitos-gnáisses e quartzo-mica-xistos do Supergrupo Rio Paraúna (Almeida Abreu et al. 1992);

- da história sedimentar e metamórfica proterozóica resultaram 4 grandes "unidades" litoestratigráficas que, através das diferenças de comportamento frente ao intemperismo e de resistência mecânica à erosão, vão controlar grande parte da formação do relevo em escala regional: unidade predominantemente quartzítica do Supergrupo Espinhaço; diques e sills de rochas metabásicas recortando a anterior; unidade predominantemente xistosa do Grupo Macaúbas e unidade pelíticocarbonática do Grupo Bambuí;

- neste quadro litológico, deve-se ressaltar a importância volumétrica assumida pelos quartzitos do Supergrupo Espinhaço (principalmente os da Formação Galho do Miguel), na parte sul, e pelos xistos do Grupo Macaúbas, na parte norte;

- as principais estruturas regionais, compostas por empurrões e dobras com vergências para $\mathrm{W}$, bem como o eixo de arqueamento Gouveia-Itacambira-Espinosa, têm direção meridiana, com variações para NNW-SSE, na parte sul, e NNE-SSW, na parte norte;

- em toda sua extensão meridiana, a escarpa da borda oeste constitui uma feição morfotectônica típica de front de cavalgamento, expressão de uma importante descontinuidade crustal (Oliveira \& Alkmim 1994) separando uma zona cratônica de uma faixa de dobramento;

- a borda leste, por sua vez, é marcada pelas intervenções sucessivas de falhas com caráter e importância variáveis, que compõem o cinturão de cavalgamentos situado na zona proximal da colisão continental que edificou o Orógeno Espinhaço.

De um ponto de vista sintético, as direções estruturais précambrianas que, além dos empurrões e dobras N-S, marcam o relevo da serra são, segundo Almeida Abreu \& Pflug (1994):

- falhas de transferência WNW-ESE (dextrais) e NW-SE (sinistrais), melhor impressas na morfologia das partes central (entre Diamantina e Santa Rita) e norte, bem como na bacia do rio Araçuaí;

- falhas NE-SW (frequentemente dextrais), melhor impressas na morfologia da parte sul e na bacia do rio Doce;

— transcorrências E-W (geralmente dextrais), com expressão morfológica nítida na Serra do Cipó.

\section{A ORGANIZAÇÃO DO RELEVO $O$ arranjo global}

Ao se considerar o alinhamento de cristas principais (acima da cota 1200m), a Serra do Espinhaço mineira parece constituir um espigão de direção norte-sul, centrado no meridiano $43^{\circ} \mathrm{W}$ (Fig. 2). Esta impressão é bastante desfeita pela observação detalhada da forma revelada pela massa de relevo contornada pela curva de nível $1.000 \mathrm{~m}$. Entre as latitudes de Belo Horizonte e Montes Claros, define-se um arco cuja convexidade é orientada para oeste, com ápice no eixo Três MariasDiamantina.

A análise da hipsometria (Fig. 2) permite observar que:

a - o alinhamento somital norte-sul é, na realidade, constituído por uma série de linhas de cristas descontínuas gerando um padrão sub-ortogonal, composto pelo cruzamento das direções próximas de NE-SW e NW-SE;

b - o maior volume topográfico é representado por um planalto de aspecto maciço, cujo teto encontra-se em altitude média de $1.300 \mathrm{~m}$, na região de Diamantina, enquanto suas extremidades declinam para cotas médias de $900 \mathrm{~m}$, ao norte, e $1.200 \mathrm{~m}$, ao sul;

c - a parte central deste planalto, também a mais elevada - correspondente ao Planalto de Diamantina (Abreu 1982) - apresenta um desenho de romboedro perfeito, definido por bordas retilíneas com direções N40E e N30W;

d - os lineamentos revelados são: N-S a NNW-SSE acima de $1.400 \mathrm{~m}$, NW-SE e NE-SW entre 800 e $1.400 \mathrm{~m}$ e NW-SE e E-W abaixo de $800 \mathrm{~m}$, com grandes eixos marginais NE-SW.

\section{Os grandes compartimentos e suas margens}

Em escala regional, a Serra do Espinhaço é subdividível em dois compartimentos de planaltos ocupando as partes sul e norte desta - muito bem diferenciados e nitidamente separados por uma zona deprimida de direção NW-SE, passando por Couto de Magalhães, a norte de Diamantina. Estes serão aqui denominados, respectivamente, Planalto Meridional e Planalto Setentrional.

\section{O Planalto Meridional}

Este compartimento inicia-se na extremidade meridional da serra, ou seja nas nascentes do rio Cipó alojadas na serra homônima, a aproximadamente $50 \mathrm{~km}$ a norte de Belo Horizonte. Nesta região, sua largura é a mais reduzida $(30 \mathrm{~km})$, aumentando rapidamente em direção a norte, para atingir $90 \mathrm{~km}$ entre Santo Antônio do Itambé e Conselheiro Mata.

A altitude média da superfície situa-se em torno de $1.200 \mathrm{~m}$, com ponto culminante em $2.062 \mathrm{~m}$, no Pico do Itambé. No geral, a hipsometria deste compartimento mostra que se trata de um plano ligeiramente convexo, ao longo de um eixo meridiano inclinado de norte para sul. A localização do eixo da convexidade próximo à borda oeste do planalto, confere à sua superfície uma certa assimetria no sentido E-W (Fig. 2).

Do ponto de vista geológico (Fig. 1), a característica fundamental é, sem dúvida, a predominância absoluta dos quartzitos que, em toda extensão do compartimento, compõem uma cobertura rígida, no entanto, densamente fraturada e cisalhada. As formas de relevo resultantes de sua esculturação pela dissecação fluvial são representadas, majoritariamente, por cristas, escarpas e vales profundos adaptados às direções tectônicas e 


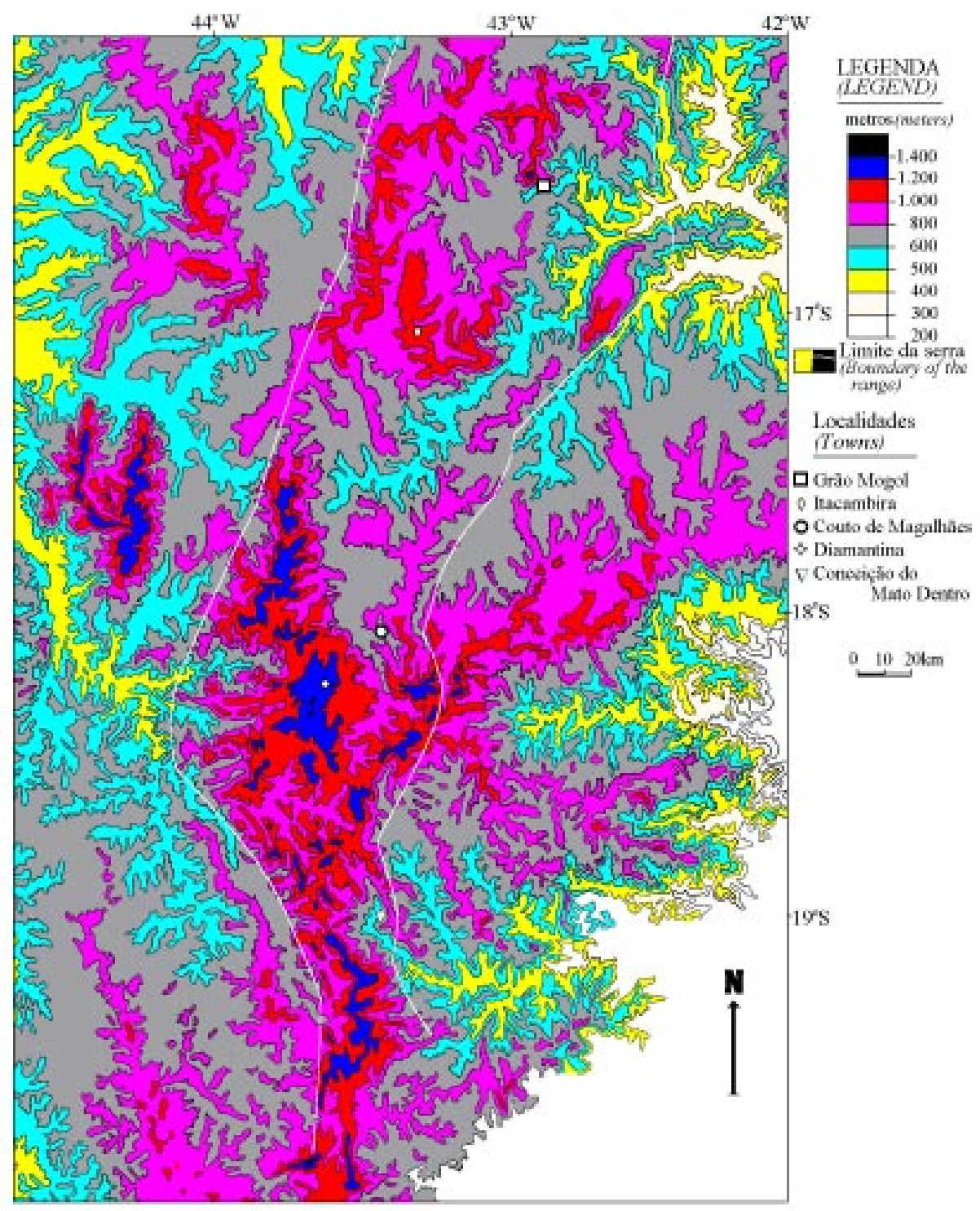

Figura 2: Mapa hipsométrico da Serra do Espinhaço e suas margens.

Figure 2: Hypsometrical map of the Serra do Espinhaço and adjacent areas.

estruturais (Foto 1). Em meio a este cenário de planalto descarnado, alojam-se uma série de áreas deprimidas, sucedendo-se num arranjo "en échelon", entre Gouveia (Foto 2) e Conceição do Mato Dentro. Nestas depressões, rochas granitóides, metassedimentares e metavulcânicas sustentam morfologias colinares policonvexas mais ou menos suavizadas.

As bordas deste compartimento, ambas nitidamente escarpadas, apresentam, no entanto, algumas diferenças morfológicas (Fig. 3) relacionadas com as respectivas posições no contexto geotectônico global.

A escarpa que forma a borda oeste apresenta altura média de $400 \mathrm{~m}$ e traçado regular, via de regra, sustentada por pacotes de quartzitos, pelo menos no topo.

No trecho meridional de direção NNW-SSE (Serra do Cipó), é clara sua relação estreita com a frente de empurrão que sobrepõe, de E para W, as sequências do Supergrupo Espinhaço e/ou do Grupo Macaúbas sobre as do Grupo Bambuí. Este caráter morfotectônico da escarpa, facilmente observado em São José de Almeida (ao lado do Morro da Pedreira) é reforçado pela persistência do escarpamento quando os quartzitos são substituídos pelos metatilitos, no trecho próximo a Presidente Juscelino.

É característico desta parte da escarpa o paralelismo mantido entre esta e os cursos d'água principais. Apenas alguns, de menor importância, a recortam perpendicularmente em trechos encachoeirados, principalmente na extremidade sul.

Entre Presidente Juscelino e Engenheiro Navarro (Serra de Minas), a escarpa assume uma altura permanente de $500 \mathrm{~m}$ e um traçado encurvado (direções NNW e NNE), com convexidade voltada para oeste. Este trecho de escarpa parece não manter relação com falhamentos, mas, indiretamente, com uma estrutura anticlinal N-S afetando as sequências do Supergrupo Espinhaço, as quais seriam recobertas discordantemente pelos metassedimentos dos grupos Macaúbas e Bambuí (Almeida Abreu \& Pflug 1994). 


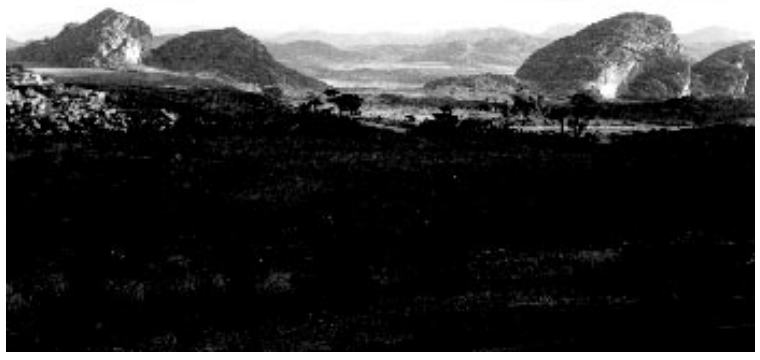

Foto 1: Vista do Planalto de Diamantina, próximo a

Guinda: superfície de aplainamento paleogênica com monadnocks quartzíticos.

Photo 1: View of the Planalto de Diamantina, near Guinda: paleogenic planation surface with quartzitic monadnocks.

São característicos deste trecho da borda oeste:

- os canyons entalhados, perpendicularmente à escarpa, por cursos d'água pertencentes à bacia do rio São Francisco, como os rios Pardo Grande, Pardo Pequeno, Preto e Jequitaí, entre outros;

- os deslocamentos da linha de escarpa, correspondendo às falhas de direção WNW-ESE, que tiveram movimentação transcorrente dextral no Proterozóico (Almeida Abreu \& Pflug 1994).

O escarpamento que constitui a borda leste do Planalto Meridional não apresenta, quanto a ele, a mesma regularidade, nem continuidade observadas em sua borda oeste. O traçado geral forma uma concavidade voltada para leste, entre Pedra Menina, ao norte, e Itambé do Mato Dentro, ao sul. No detalhe, trata-se de um escarpamento descontínuo, com altura variável entre 100 e $400 \mathrm{~m}$, frequentemente composto por 2 ou mais degraus e bruscas mudanças de direção (Fig. 3a,c). Aparentemente, esta configuração parece resultar da combinação entre a importante variabilidade

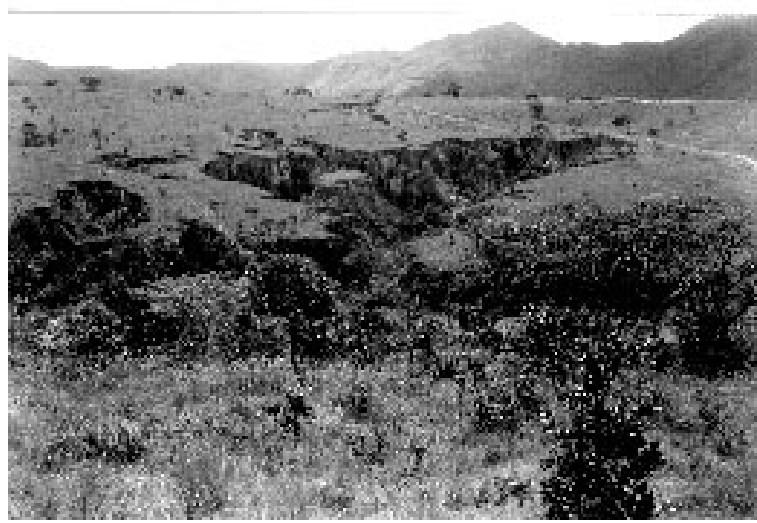

Foto 2: Vista da Depressão de Gouveia: superfície paleogênica $(1.250-1.300 m)$ no terceiro plano; superfície pliocênica (1.050 - 1.100m) no segundo plano e vales quaternários com voçorocas, em primeiro plano.

Photo 2: View of the Depressão de Gouveia: paleogenic surface $(1.250-1.300 \mathrm{~m})$ in the third plane; pliocenic surface $(1.050-1.100 \mathrm{~m})$ in the second plane and quaternary valleys with voçorocas, in the first plane.

de resistência das rochas que lá se entremeiam (quartzitos e conglomerados versus granitóides e xistos) e a também grande variabilidade de estruturas tectônicas e suas direções. Estas combinações ocasionam um avanço diferenciado da frente de dissecação movida pelos afluentes de margem esquerda do rio Doce, que penetram profundamente esta parte do planalto, ao longo das janelas estruturais NNW-SSE, localizadas entre as frentes de empurrão vergentes para W (ao exemplo do rio Santo Antônio, na região de Conceição do Mato Dentro).

O trecho mais setentrional, entre Serro e Pedra

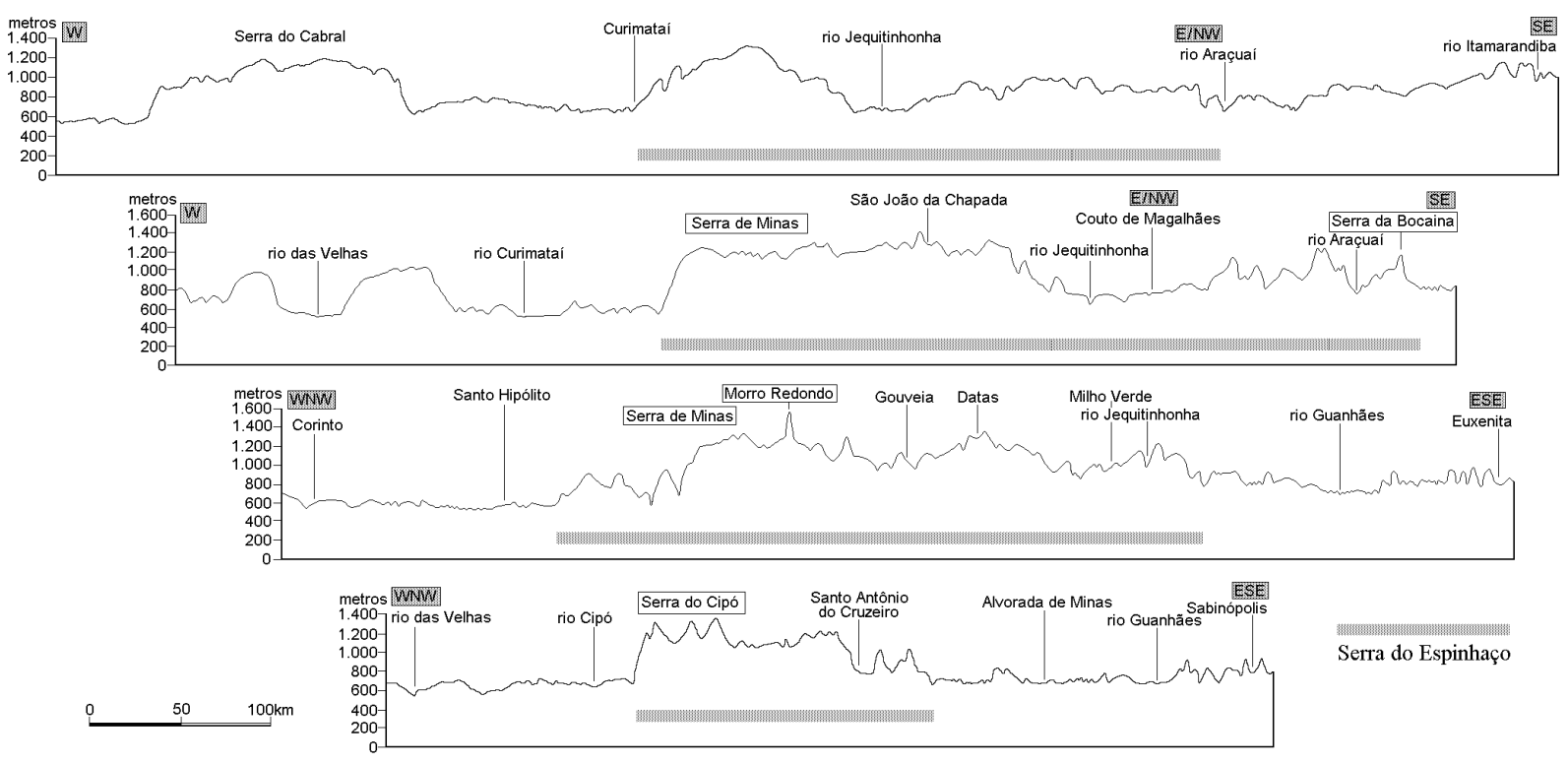

Figura 3: Perfis morfológicos do Planalto Meridional.

Figure 3: Morphological sections of the Planalto Meridional. 
Menina, apresenta a particularidade do escarpamento mais retilíneo, com direção N30E, apesar de densamente recortado pela zona de cisalhamento NWSE que controla a Depressão de Couto de Magalhães (Fig. 3b). É nesta região que encontram-se as maiores altitudes de toda a Serra do Espinhaço: 2.062m no Pico do Itambé, $1.759 \mathrm{~m}$ na Serra da Bicha, $1.628 \mathrm{~m}$ a oeste de Serra Azul de Minas, entre outros.

\section{O Planalto Setentrional}

Este compartimento inicia-se logo a norte de Couto de Magalhães e estende-se além da fronteira Minas Gerais-Bahia. Alonga-se em direção NNE com comprimento e largura de, respectivamente, 340 e $100 \mathrm{~km}$. A sua morfologia, radicalmente diferente da do Planalto Meridional, tem sido descrita por Saadi (1991), como composta por (Fig. 4):

a - um plano fundamental, extraordinariamente regularizado e inclinado em direção $\operatorname{ESE}(0,20 \%)$, entre Francisco Sá $(1.050 \mathrm{~m})$ e Leliveldia (800m), constituindo um platô perfeito, apesar de sua subdivisão em inúmeras chapadas isoladas por profundos e estreitos vales (Foto 3 e 4);

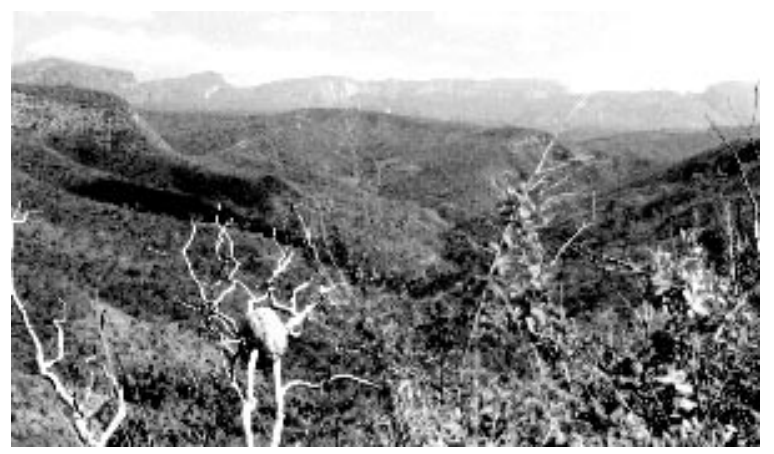

Foto 3: Um aspecto do Planalto Setentrional: monadnock quartzítico, no último plano, chapadas da superfície paleogênica e vales plio-quaternários, no primeiro plano.

Photo 3: One aspect of the Planalto Setentrional: quartzitic monadnock in the last plane, plateaux of the paleogenic surface and plio-quaternary valleys, in the first plane. b - linhas de cristas quartzíticas de direção N-S, com altitude máxima de $1.467 \mathrm{~m}$ (Serra da Samambaia, a SW de Botumirim), formando um espigão protuberante no meio do planalto (Foto 3);

c - uma zona ligeiramente deprimida, com relação ao plano fundamental, inserida paralelamente em meio às cristas quartzíticas e ocupada por colinas gnáissicas entre Itacambira e Espinosa.

Esta constituição morfológica encontra respaldo em características lito-estruturais específicas deste compartimento. O plano fundamental do planalto foi elaborado sobre metassedimentos (quartzitos, xistos, filitos, metatilitos) do Grupo Macaúbas, estruturados e dobrados com vergência para oeste. As cristas quartzíticas centrais correspondem a lascas de empurrão com mesma vergência envolvendo sequências do Supergrupo Espinhaço. A depressão gnáissica é o resultado da escavação fluvial de uma janela estrutural equivalente à de Gouveia, no Planalto Meridional.

Ambas as bordas do Planalto Setentrional apresentam relações diretas com estruturas tectônicas précambrianas de $1^{\mathrm{a}}$ ordem (Pedrosa-Soares et al. 1992).

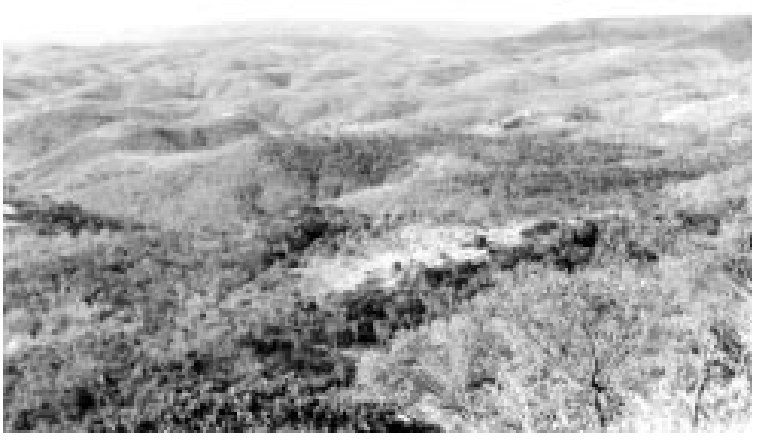

Foto 4: Vista do Planalto Setentrional a oeste de Virgem da Lapa: superfície paleogênica exumada e tectonicamente rebaixada, à esquerda, e tabuleiros pliocênicos, à direita.

Photo 4: View of the Planalto Setentrional west of Virgem da Lapa: paleogenic surface (exhumed and tectonically lowered) to the left, and pliocenic plateaux, to the right.

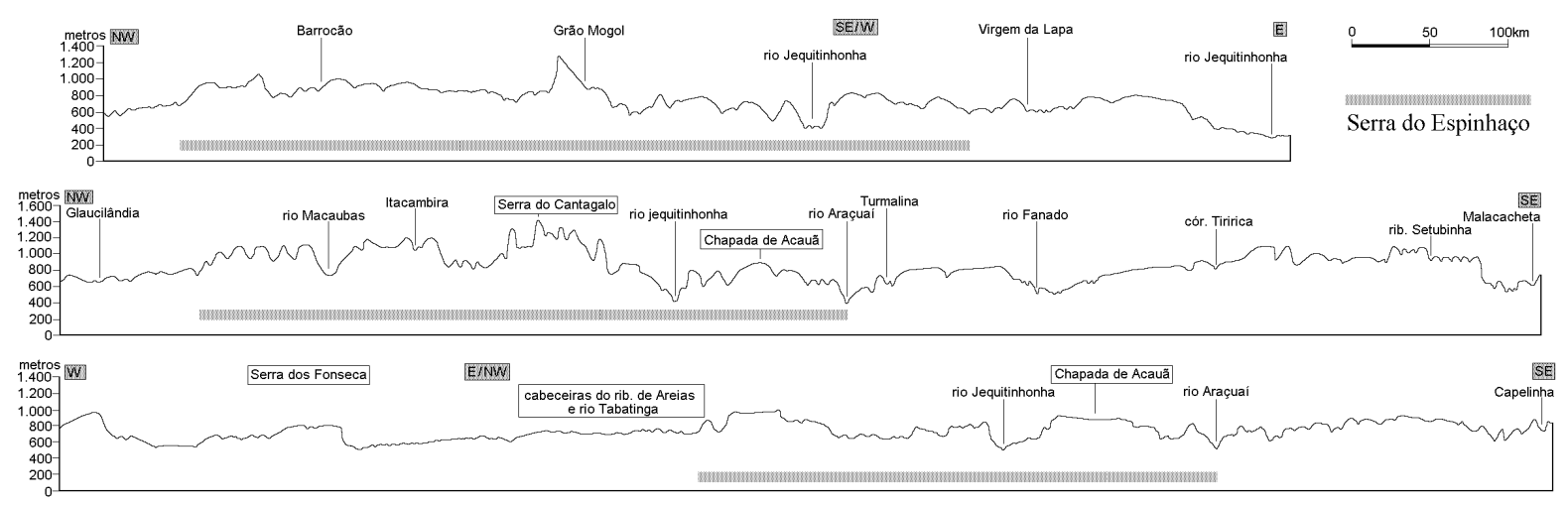

Figura 4: Perfis morfológicos do Planalto Setentrional.

Figure 4: Morphological sections of the Planalto Setentrional. 
A borda oeste é marcada por uma escarpa de direção NNE-SSW, com altura média superior a $200 \mathrm{~m}$, sendo adaptada a uma das principais falhas de empurrão. No entanto, esta escarpa só se afirma com traçado rígido, ao norte de Bocaiúva, pois a SE desta localidade, ela é interrompida pela depressão fluvial do ribeirão de Areias e rio Tabatinga. Estes são os únicos afluentes diretos do rio Jequitinhonha que têm suas nascentes localizadas fora da cordilheira, no prolongamento NW da Depressão de Couto de Magalhães.

A borda leste subdivide-se em dois segmentos. $\mathrm{O}$ meridional, ao sul de Turmalina, é retilíneo em direção SW-NE, sentido em que a altura da escarpa varia de 0 a 200m. Esta, bem como o vale do rio Araçuaí, são controlados por uma falha de movimento normal no Neocenozóico (Pedrosa Soares \& Saadi 1989, Saadi 1991). A norte de Turmalina, o escarpamento perde muito de sua imponência e nitidez, apesar do controle exercido pela Falha de Taiobeiras, outra importante falha de empurrão de direção geral NNE-SSW.

\section{A Depressão de Couto de Magalhães}

Esta depressão, denominada "Rasgo Interplanáltico da Cordilheira do Espinhaço" por Saadi (1991), expressa os resultados de uma vigorosa dissecação fluvial, realizada até a cota $700 \mathrm{~m}$, por cursos d'água associados aos altos rios Araçuaí e Jequitinhonha. Estes realizaram o seu trabalho ao abrigo da barreira estabelecida pela crista quartzítica de Serro-Pedra Menina, contra as tentativas de avanço, para NW, das cabeceiras dos afluentes do rio Doce (rios Suaçuí Grande, Corrente Grande e Guanhães).

$O$ vigor da dissecação encontra explicação na associação entre diminuição da resistência litológica (afloramento de litotipos do Grupo Macaúbas) e falhamentos de direção NW-SE. Deve-se ressaltar, por outro lado, que nesta região, o rio Jequitinhonha sofre um importante transporte em direção NW, onde recebe o ribeirão de Areias e rio Tabatinga, únicos afluentes que ultrapassaram os limites ocidentais da Serra do Espinhaço.

\section{A HIDROGRAFIA}

Sendo a Serra do Espinhaço um dos mais importantes divisores hidrográficos do Sudeste Brasileiro, não se poderia tratar de sua hidrografia antes de situá-la no contexto regional.

\section{A hidrografia no contexto supra-regional}

A figura 10 mostra que o já referido encurvamento da Serra do Espinhaço é refletido no traçado do conjunto formado pelo rio São Francisco e seus mais importantes afluentes de margem direita. A serra funciona como divisor fundamental entre este conjunto e aquele composto por todas as bacias que irrigam o leste mineiro e desaguam no oceano, no sul da Bahia e norte do Espírito Santo. Curiosamente, as cabeceiras deste último conjunto vão se concentrar na grande concavidade formada pela borda leste da serra, enquanto suas desembocaduras espalham-se por centenas de quilômetros de litoral, quando o esperado é justamente o contrário!

\section{O arranjo das bacias regionais e de seus divisores}

As figuras 2 e 5 mostram que o essencial da drenagem da serra pertence à bacia do rio São Francisco, para o Planalto Meridional, e à bacia do rio Jequitinhonha, para o Planalto Setentrional.

No caso do Planalto Meridional, uma estreita faixa da borda leste foi conquistada pelos afluentes de margem esquerda do rio Doce, enquanto o Planalto de Diamantina abriga as cabeceiras do Alto Jequitinhonha.

No caso do Planalto Setentrional, a margem oeste é palco de uma importante oscilação, no sentido E-W, do divisor São Francisco-Jequitinhonha. Enquanto ao sul, o ribeirão de Areias e o rio Tabatinga estendem suas cabeceiras até próximo a Bocaiúva, sobre a área cratônica, mais ao norte, são as cabeceiras de afluentes do rio São Francisco que empurram gradualmente o divisor para dentro do planalto, até dividir seu espaço com os formadores do rio Pardo. Na borda leste, uma estreita faixa é ocupada, de sul para norte, por afluentes dos rios Araçuaí, Vacaria e Pardo.

Percebe-se, portanto, que o Planalto de Diamantina assume a função de ponto irradiador das drenagens dos rios São Francisco, Doce, Jequitinhonha e Araçuaí, confirmando seu caráter de teto orográfico regional. Por outro lado, deve-se ressaltar que em toda a borda oeste da Serra do Espinhaço, a frente de dissecação sanfranciscana atinge a superfície dos planaltos, exceto na região de Bocaiúva, onde o divisor é recuado a oeste pelas cabeceiras do ribeirão de Areias e rio Tabatinga. Nota-se que esta região se localiza na projeção da Depressão de Couto de Magalhães, cuja direção NWSE corresponde também à do Planalto de Diamantina e da bacia do Alto Jequitinhonha.

\section{A drenagem e as estruturas tectônicas}

A análise dos perfis longitudinais dos cursos d'água será, por razões compreensíveis, limitada à bacia do rio Jequitinhonha (Fig. 6). O perfil do rio Jequitinhonha apresenta quedas brutais em Salto da Divisa e em Terra Branca - em meio ao Planalto Setentrional relacionadas mais com estruturas tectônicas do que com soleiras rochosas. Nota-se que, após a cabeceira com declividade de $0,55 \%$, o trecho situado entre Terra Branca e Araçuaí é o único a apresentar declividade elevada $(0,17 \%)$. Terra Branca parece representar um nível de base local, que controla o alto curso e limita o avanço da frente de dissecação em direção ao sul. O rio Araçuaí, livre da resistência oposta pelos quartzitos do Supergrupo Espinhaço, possui um perfil mais homogêneo, apesar de sempre mais declivoso. Além disso, seu baixo curso aprofunda-se mais rapidamente que o do rio Jequitinhonha, dreno hierarquicamente superior.

O controle estrutural e/ou tectônico da drenagem é expresso por feições variadas, em função do nível de abordagem. 


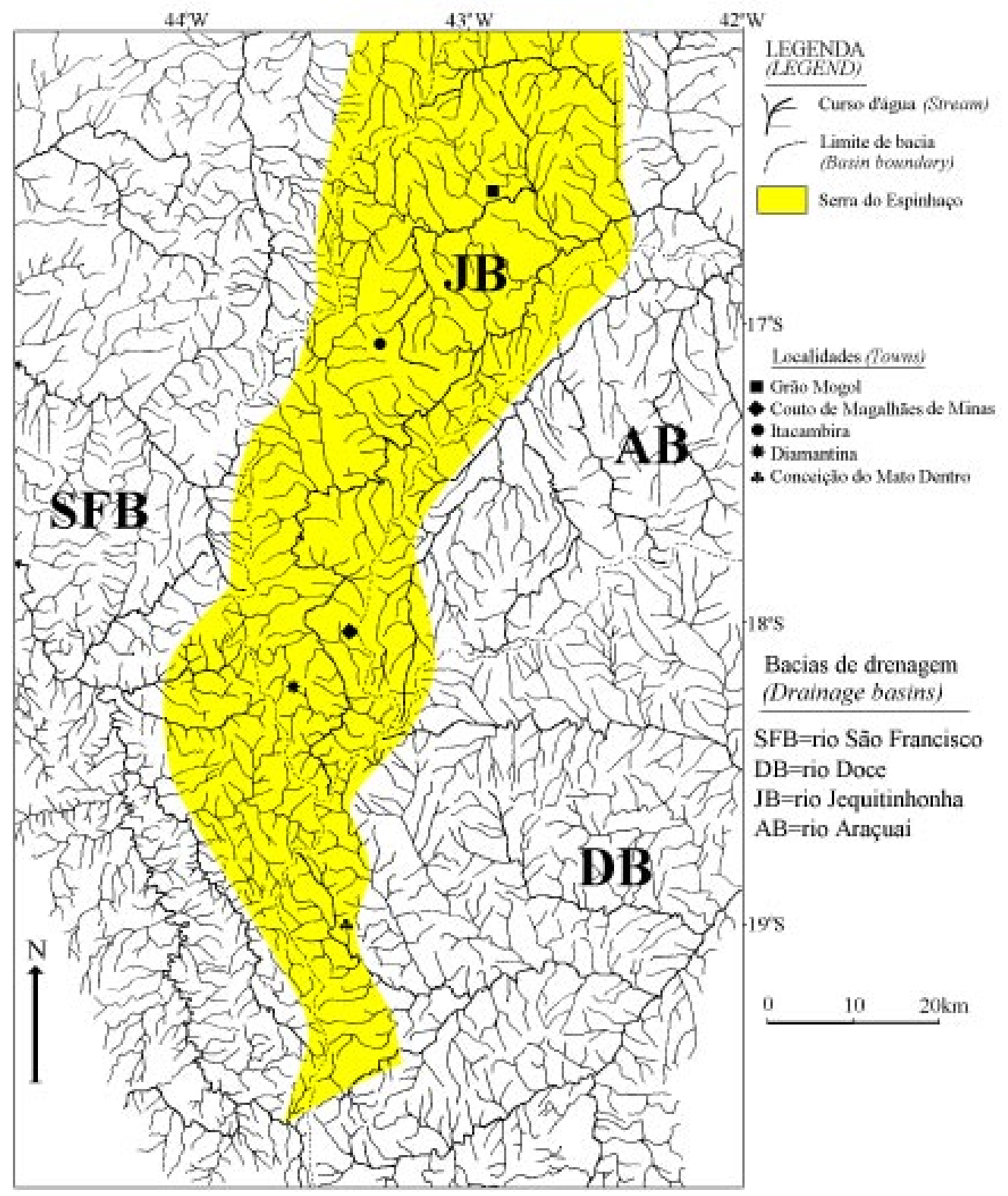

Figura 5: Mapa da rede hidrográfica da Serra do Espinhaço e suas margens.

Figure 5: Map of the drainage system of the Serra do Espinhaço and adjacent areas.

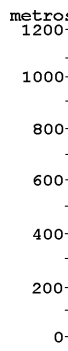

$\left.\begin{array}{r}\text { netros } \\ 1200 \\ 1000 \\ 800- \\ 600- \\ 60- \\ 400- \\ 200- \\ 0\end{array}\right]$
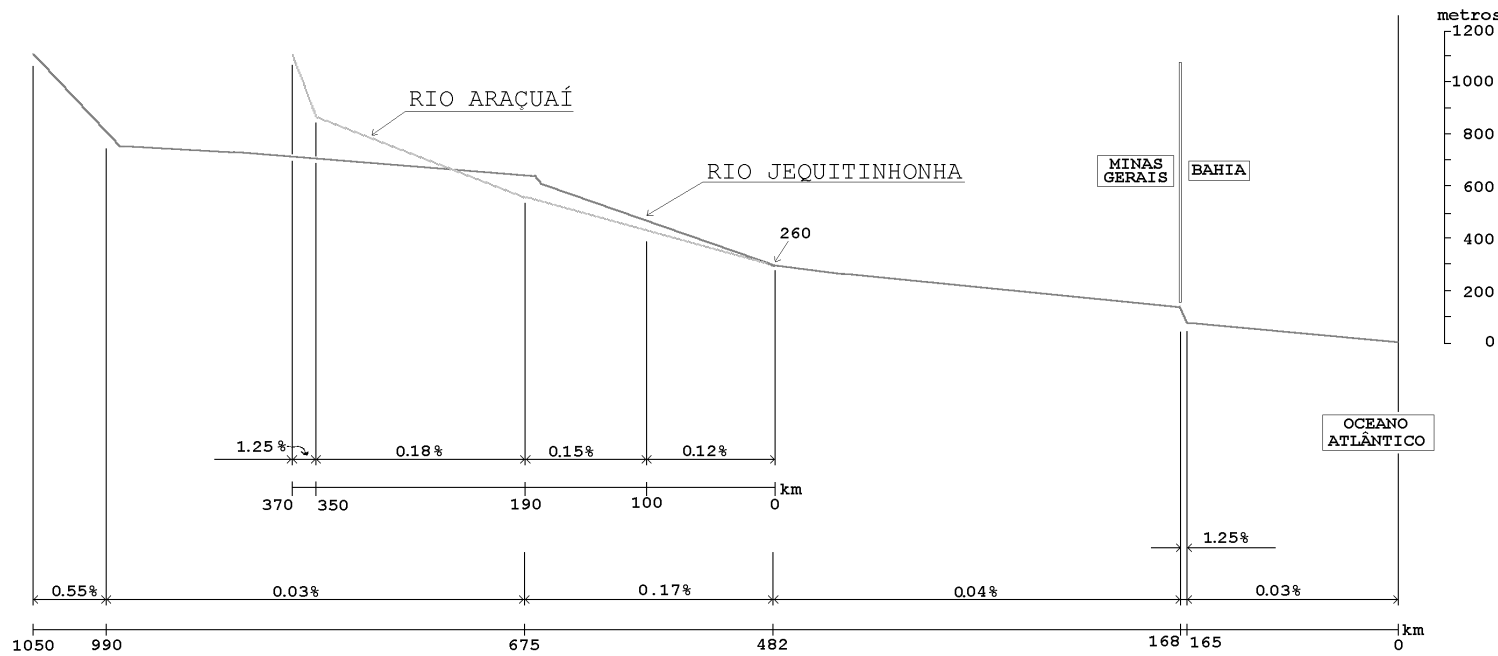

Figura 6: Perfis longitudinais dos rios Jequitinhonha e Araçuaí (fonte: CETEC-MG 1980).

Figure 6: Longitudinal profiles of Jequitinhonha e Araçaí Rivers. 
a - No nível geral, são os alinhamentos de cursos d'água, com duas direções principais sub-ortogonais; respectivamente, N30W e N40E, no Planalto Setentrional, e N30W e N50E na Serra do Cipó, onde a primeira apresenta importante concentração. Localmente, ocorrem feixes de alinhamentos em direções específicas: N60-70W e E-W, no Planalto de Diamantina, E-W no sul da Serra do Cipó, correspondendo, via de regra, a zonas de cisalhamento transcorrentes nucleadas no Proterozóico.

b - A nível dos compartimentos, pode-se eleger algumas feições, que ilustram de maneira especial esta relação.

No Planalto Setentrional, a grande curvatura do rio Itacambiruçu - que tem rumo inicial para NW, inflete para NE e, em seguida para SE - deve corresponder a uma captura cenozóica de um antigo afluente da drenagem sanfranciscana, ligada a um basculamento do planalto para SE (King 1956, Saadi 1991). A este respeito, deve-se considerar o grande número de windgaps que orlam a borda oeste, a SE de Francisco Sá, entre as cotas 900 e $1.000 \mathrm{~m}$, como testemunhos das antigas ligações com a drenagem sanfranciscana.

Este basculamento teve efeito semelhante mais a sul, onde as altas bacias do ribeirão de Areias e rio Tabatinga, afluentes do rio Jequitinhonha, parecem resultar de recente captura de drenagem sanfranciscana. Esta área, localizada na extremidade NW da Depressão de Couto de Magalhães e ocupando um bloco de orientação NNE-SSW, é limitada a oeste pelo lineamento Guaraciana-Engenheiro Dolabela que deve corresponder a uma frente de empurrão. É significativo que várias cabeceiras de drenagem adotam um rumo inicial para W. Além disso, o conjunto de sua drenagem possui uma estrutura ainda primitiva, com caráter pantanoso e de águas-emendadas

c - Feições com expressão e significado locais, também, ocorrem em todas as partes da serra.

Saadi (1991) descreveu as características especiais dos controles tectono-estruturais na Serra do Cipó, com longos trechos de planícies com formas amendoadas, controlados por falhas de empurrão NNW-SSE e curtos trechos encachoeirados ao longo de transcorrências E-W a N70W (Fig. 7a). No local denominado "Travessão", a SE de Cardeal Mota, a combinação dessas duas estruturas induziu a formação de um canyon bi-direcionado com desníveis verticalizados de centenas de metros (Fig. 7b).

Abreu (1982) descreveu vários esquemas de pequenas capturas no Planalto de Diamantina, atribuídas por ele a falhamentos locais, mas que reinterpretamos agora como efeitos locais de um falhamento de expressão regional. Segundo este autor, a NW de Sopa, o atual alto ribeirão do Caldeirão atingia o ribeirão da Areia, através do córrego São Nicolau, enquanto o córrego das Pedras constituía um afluente do ribeirão do Caldeirão, antes de ambos serem desviados para leste. A sul de Diamantina, a atual bacia do alto córrego Rapadura teria sido, em tempos históricos, afluente do córrego Candinhos, rumando para SE logo a jusante da antiga Fazenda Casa de Telha. Seu rumo direto para leste resultaria de uma captura com causas antrópicas. Nesta área, King (1956), também, faz referência a capturas operadas pelo rio São Bartolomeu.

As observações de campo permitem confirmar essas interpretações locais. No entanto, existe um lineamento N30W, cortando toda a região entre São João da Chapada e Vau, paralelamente ao atual divisor São Francisco-Jequitinhonha, bem próximo, e que liga as duas áreas com ocorrências de capturas. Seu prolongamento, a SE, corta o rio Jequitinhonha em Vau, onde em conformidade com a etimologia do termo, o leito fica mais largo e raso em meio a uma planície. Nesta, o último período de aluvionamento, forçado pelo estreitamento em canyon situado logo a jusante, deixou $4 \mathrm{~m}$ de sedimentos rudáceos e arenosos.

\section{OS MARCOS DA EVOLUÇÃO GEOMORFOLÓGICA}

Uma vez esboçado o ambiente geológico (geotectônico global, litológico e tectono-estrutural) e descritas as principais características morfológicas e hidrográficas da Serra do Espinaço, tem-se um quadro referencial suficiente para a inserção de informações de cunho geomorfológico, que assumem então o papel de marcos e/ou testemunhos da evolução do relevo. A sua apresentação regionalizada resulta do próprio caráter esparsado dos estudos que os geraram. Tentarse-á, ao final deste trabalho, uma interpretação global, baseada na análise dos resultados dos diversos autores.

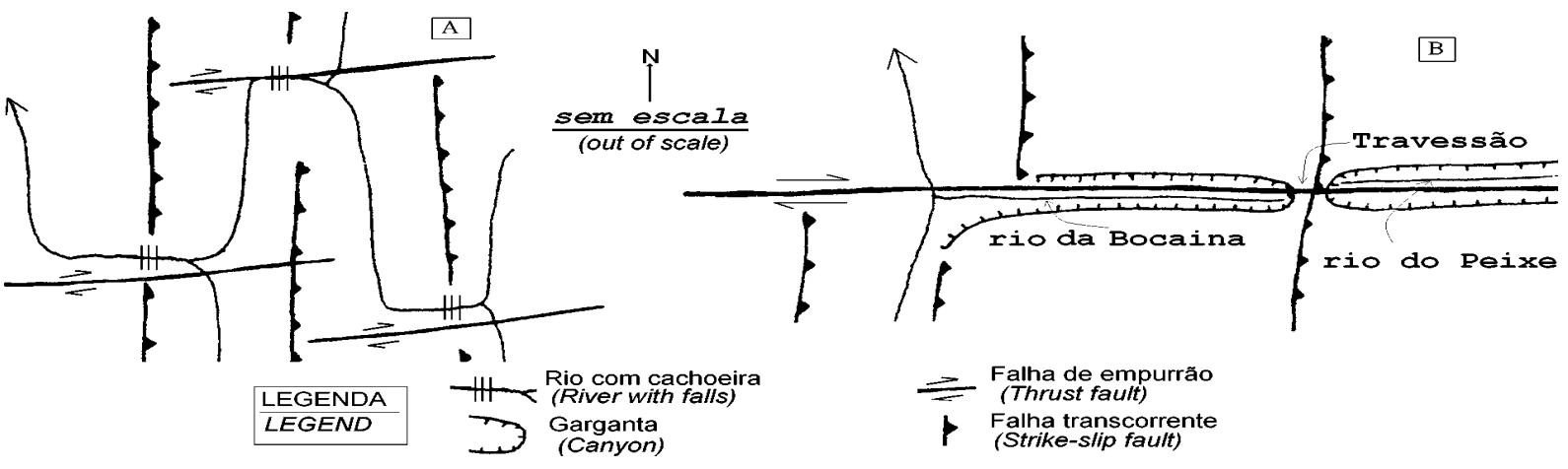

Figura 7: Aspectos do controle tectônico da drenagem na Serra do Cipó (Saadi 1991).

Figure 7: Aspects of the tectonic control of the drainage system in the Serra do Cipó. 


\section{Formas e depósitos no Planalto Meridional e suas margens}

Informações especificamente geomorfológicas sobre áreas pertencentes ao Planalto Meridional resultam de trabalhos com abrangências desiguais.

O primeiro trabalho digno de interesse, realizado por Brajnikov (1947), trata da Serra do Espinhaço como um todo, concentrando, no entanto, suas observações na parte meridional. $\mathrm{O}$ autor responsabilizou a atuação de "uma tectônica de fundo realizada ao ar livre" com caráter compressivo, pela inclinação dos planaltos para leste, cavalgamentos locais, importantes deslocamentos e o arqueamento da bacia do São Francisco sob forma de braquianticlinal. Uma $2^{\mathrm{a}}$ fase, distensiva, teria interrompido o $1^{\circ}$ ciclo de aplainamento (pliocênico), atualmente localizado na cota média de $1.200 \mathrm{~m}$ e gerado o horst da Serra do Espinhaço e a "fossa" do vale do rio das Velhas, com deslocamento vertical de $1.000 \mathrm{~m}$. A continuação do soerguimento durante o Quaternário teria induzido, no Quadrilátero Ferrífero, a formação de 4 terraços escalonados, além do nível da várzea.

King (1956) reconhece, na Serra do Cipó, restos da Superfície Gondwana (Cretáceo Inf.-Méd.) em altitude de $1.800 \mathrm{~m}$, da Pós-Gondwana (Cretáceo Sup.Paleoceno) no Alto do Palácio, a $1.400 \mathrm{~m}$, e da Sulamericana (Eoceno-Oligoceno) na borda da serra, a 1.100-1.200m. A depressão ocupada pelos rios Cipó e das Velhas, sobre o Cráton do São Francisco, corresponderia ao abatimento tectônico desta última, resultando num deslocamento de 300 a 400m.

No Planalto de Diamantina, o nível gondwânico subsistiria sob forma de alinhamento NW-SE, entre Serro e Diamantina, desaparecendo no Planalto Setentrional. Nesta região, o nível pós-gondwânico seria representado pelo platô ondulado entre 1.250 e $1.300 \mathrm{~m}$ (Foto 1). A oeste de Guinda, restos do mesmo a $1.400 \mathrm{~m}$, formando o atual divisor de drenagem São FranciscoJequitinhonha, testemunhariam a localização do eixo de arqueamento da serra no final do Terciário. No Planalto Setentrional, este nível seria representado pelos topos das cristas quartzíticas (1.300m, em Grão Mogol). A Superfície Sulamericana, por sua vez, mostraria uma inclinação de W para E, entre $800 \mathrm{~m}$, na região de Serro e mais de $1.000 \mathrm{~m}$, na borda oeste. Esta inclinação seria, também, observada perto de Conceição do Mato Dentro. No Planalto Setentrional, esta superfície corresponderia ao referido plano fundamental, em altitude média de $1.000 \mathrm{~m}$ (Foto 3). Apoiando-se na existência dos supostos testemunhos de um nível gondwânico, concluiu o autor que: a) a serra constitui um divisor de drenagem desde o Cretáceo; b) houve, desde então, 3 ou 4 eventos de deformação por arqueamento; c) o eixo de arqueamento migrou de oeste para leste. Por fim, afirmou esse autor que se a borda oeste é marcada por uma escarpa de falha normal, a oriental corresponde somente a um "arqueamento sem falhamento".

\section{No Planalto de Diamantina}

No Planalto de Diamantina, Abreu (1982) ${ }^{(*)}$ define três níveis escalonados no relevo regional, correspondentes àqueles propostos por King (1956).

O Nível 3 (Post-Gondwana), entre 1.200 e $1.400 \mathrm{~m}$, é arqueado ao longo de um eixo meridiano que, sendo localizado "entre as nascentes do ribeirão Datas até um pouco ao norte de Guinda", acima da cota $1.400 \mathrm{~m}$, forma, localmente, o divisor São-Francisco-Jequitinhonha. As abas têm inclinações para WSW (em direção a Conselheiro Mata) e ENE (em direção a Diamantina). Sua superfície comportaria inselbergs quartzíticos (o que o qualifica como legítimo pediplano?), couraça ferruginosa associada a afloramentos de filitos hematíticos e brejos em depressões hidromórficas de nascentes (dale), onde ocorrem turfeiras sobrepostas a areias e cascalhos fluviais e/ou coluviais e cobertas por solos arenosos.

O Nível 2 (Superfície Sulamericana), embutido no precedente em altitude de $1.000-1.100 \mathrm{~m}$, ocorre sob forma de retalhos verticalmente desnivelados por falhas normais com direção predominante NW-SE. Os deslocamentos ocorridos na área a SW de Conselheiro Mata teriam atingido fragmentos residuais do Nível 3. O nível 2 é caracterizado por jazidas de manganês com até $2 \mathrm{~m}$ de espessura, que seriam responsáveis pela preservação dos retalhos situados na borda oeste.

O Nível 1 (Ciclo Velhas) corresponde ao mais alto terraço de cascalho $(750-800 \mathrm{~m})$, tendo sido embutido no precedente como, por exemplo, ao longo do rio Jequitinhonha a jusante de Mendanha. Porém, estranhamente, o autor atribui a formação deste nível a uma "última fase de pedimentação", datada do último período glacial do Hemisfério Norte (Würm, Wisconsin).

\section{Na Depressão de Gouveia}

A Depressão de Gouveia (Foto 2) corresponde à escavação de gnaisses e xistos arqueanos, justapostos aos quartzitos proterozóicos por uma tectônica de empurrão e nappes (Almeida-Abreu et al. 1992, Rolim 1992).

Nesta região, Saadi \& Valadão (1987a, b) definiram 4 níveis geomorfológicos (Fig. 8a). Acima de 1.300m, relevos residuais quartzíticos, tectonicamente alinhados, deveriam corresponder a restos de superfície cretácica. Entre 1.250 e $1.300 \mathrm{~m}$, uma superfície dissecada (Sulamericana) trunca rochas arqueanas e proterozóicas. Esta sustenta formações superficiais constituídas por lençois de areias quartzosas cobrindo couraça ferruginosa de acumulação absoluta, sobre filitos hematíticos e/ou rochas metabásicas; laterita ferruginosa nodular, sobre os glacis quartzíticos (Foto 5); e turfeiras, no fundo das depressões hidromórficas de cabeceiras (Foto 6). Na depressão, entre 1.050 e $1.100 \mathrm{~m}$, os topos de colinas compõem um nível de aplainamento pliocênico sobre gnaisses e xistos, embutido no precedente. Este nível é marcado por um depósito de seixos e blocos de quartzo sub-arredondados sotoposto a areias grossas, e se interliga às escarpas marginais por rampeamentos suaves. Por fim, entre 950 e $1.000 \mathrm{~m}$, desenvolvem-se vales, ainda em processo de aprofundamento.

Nas encostas das colinas da bacia do ribeirão do

(*) O trabalho trata da classificação das formas de relevo do Planalto de Diamantina. Infelizmente, só dispusemos de uma cópia do volume de texto, expurgada das ilustrações. 
Chiqueiro, ocorrem várias feições denudacionais e deposicionais, cujo arranjo comporia o perfil tipo ilustrado pela figura $8 \mathrm{~b}$. O topo, geralmente aplainado, é sustentado pelos depósitos rudáceos e arenosos, fluviais, do nível pliocênico. A rampa do anfiteatro superior corresponde aos remanescentes de uma rede hidrográfica plio-pleistocênica, testemunhada por camadas de siltitos, areias e argilitos (até $8 \mathrm{~m}$ de espessura), intercalados por lentes de cascalho anguloso e sobrepostos a pavimentos rudáceos de origem local. Constituem pacotes compactos, com cores variegadas, e são embutidos em topos e encostas, sob forma de paleo-canais fossilizados por um espesso lençol de areias vermelhas (até $5 \mathrm{~m}$ ). Este representa, provavelmente, uma fase de entulhamento aluvial da depressão, na interface Plioceno-Pleistoceno.

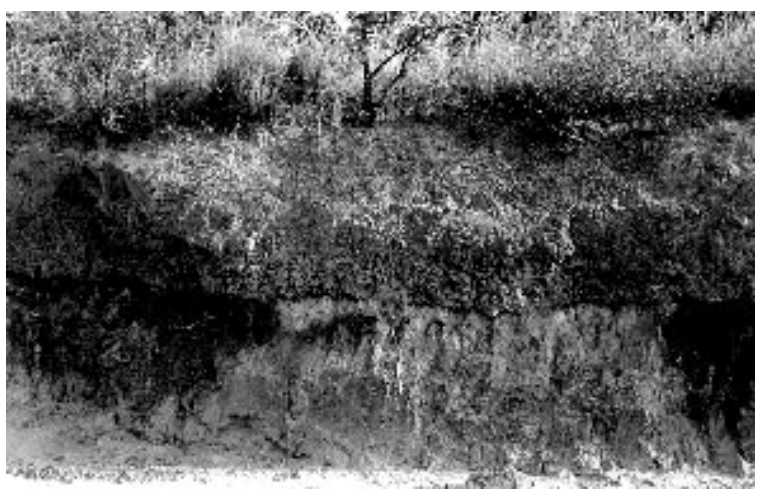

Foto 5: Coberturas dos glacis da superfície paleogênica, próximo de Guinda: areias finas sobre laterita detrítica.

Photo 5: Surficial deposits of the glacis of the paleogenic surface, near Guinda: fine sands on detrital laterite.

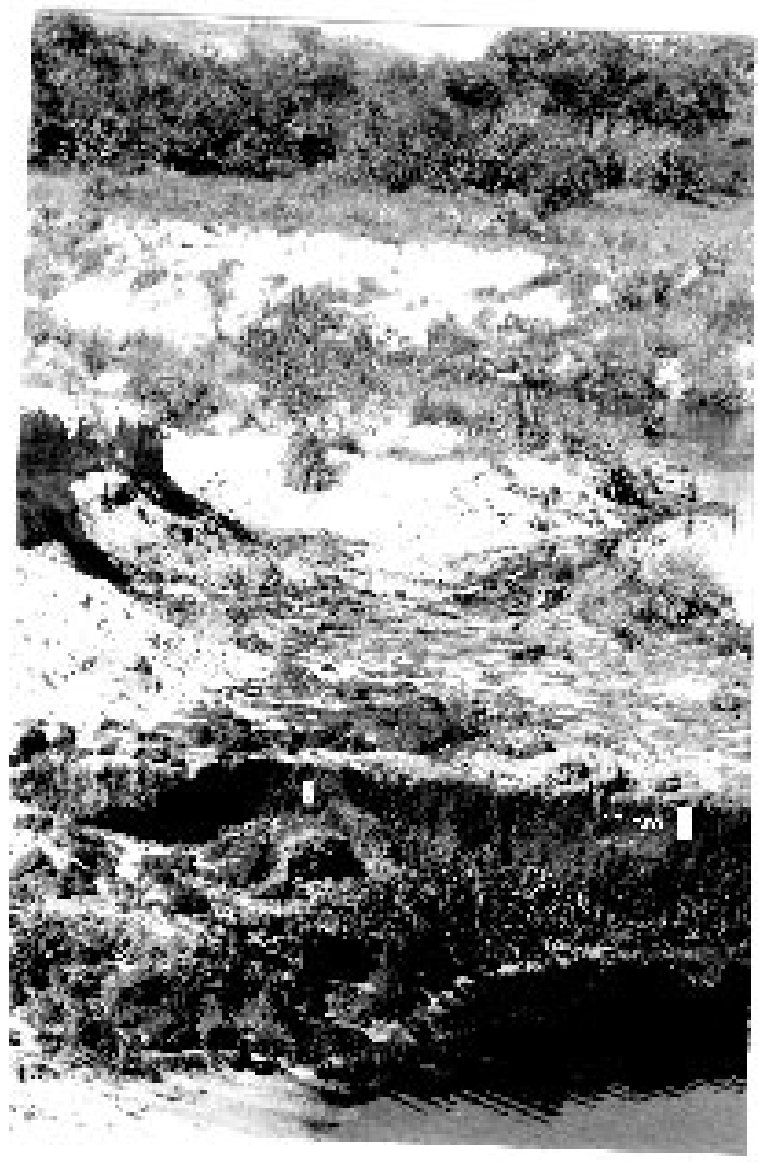

Foto 6: Cobertura das depressões hidromórficas situadas sobre as superfícies quartzíticas (córrego Lajedão, próximo a Milho Verde): areias finas sobre turfas.

Photo 6: Surficial deposits of the dales situated on the quartzitic surfaces (Lajedão River, near Milho Verde): fine sands on peat.

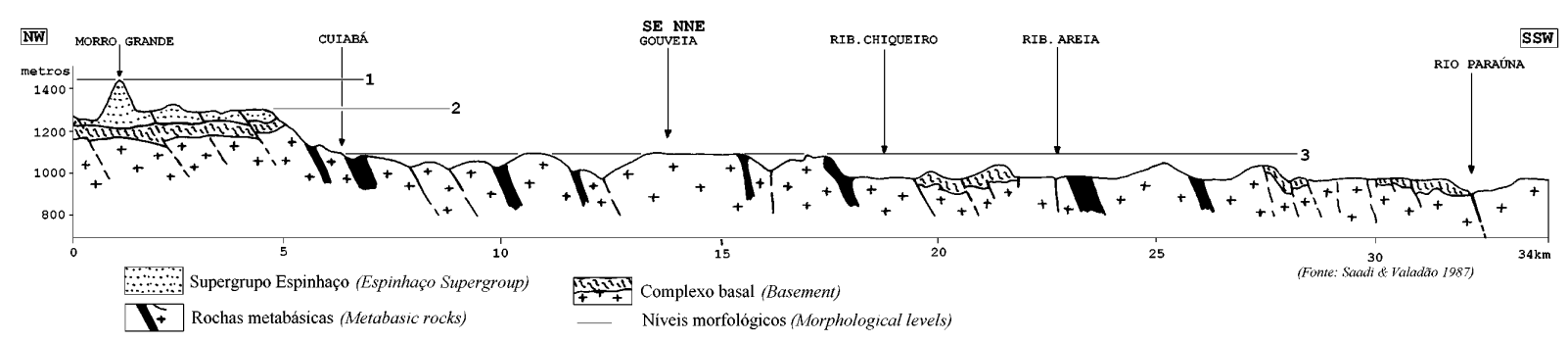

Figura 8a: Perfil geomorfológico da Depressão de Gouveia. Figure 8a: Geomorphological section of the Depressão de Gouveia.

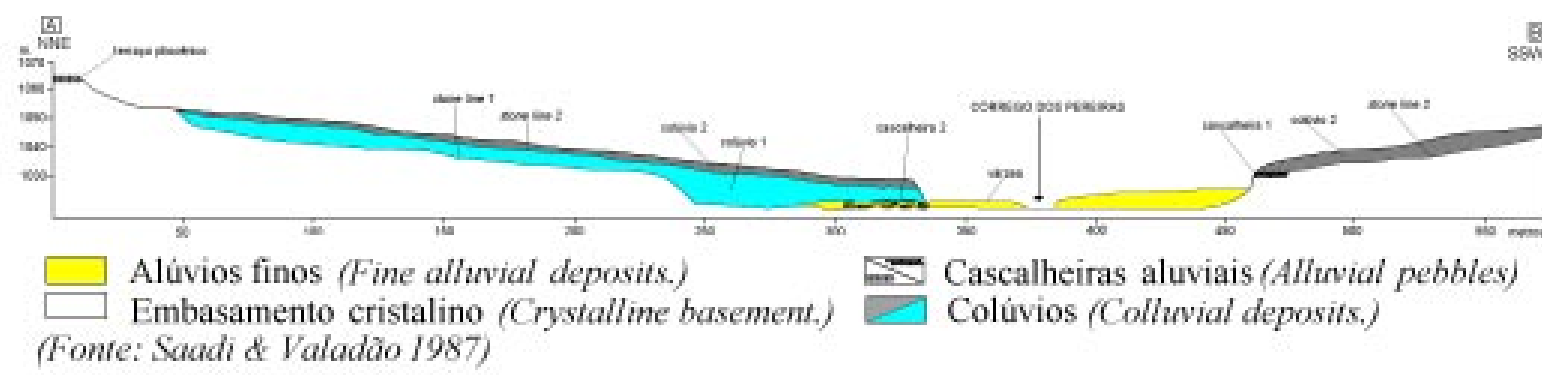

Figura 8b: Seção transversal representativa em vale da Depressão de Gouveia.

Figure 8b: Cross section in a valley of the Depressão de Gouveia. 
Os principais eventos propriamente pleistocênicos sucederam-se na seguinte sequência cronológica:

- dissecação fluvial (Pleistoceno Inferior), estabelecendo desde já o traçado da rede hidrográfica atual e deixando uma cascalheira de quartzo em altura média de 10m;

— dissecação fluvial (final do Pleistoceno Médio), aprofundando a calha por mais $9 \mathrm{~m}$, testemunhada por uma sequência ordenada de seixos e areias $($ esp. $=1 \mathrm{~m})$, assentada na altura de $1 \mathrm{~m}$;

- entulhamento dos vales com, aproximadamente, $3 \mathrm{~m}$ de areias com lentes de cascalho e argilas orgânicas, perfazendo gradualmente uma planície meândrica (Pleistoceno Superior);

- afogamento e regularização da morfologia por um primeiro evento coluvial, hoje representado por areias e siltes vermelhos, sobrepostos a uma stone line delgada, composta por fragmentos de quartzo e revelando a ocorrência de um fraca dissecação em "V" da paisagem anterior;

— após uma fraca dissecação por "vales em berço", desenhada por uma segunda stone line, espalhou-se uma segunda cobertura coluvial areno-siltosa amarela;

- com esta segunda fase de coluvionamento, o entulhamento total dos vales, abertos já no Pleistoceno Inf., deve ter realçado o nível de base em, aproximadamente, $10 \mathrm{~m}$;

- finalmente, a passagem Pleistoceno Sup.Holoceno foi marcada por uma reabertura completa dos vales, acrescida de um entalhe suplementar da calha de $1 \mathrm{~m}$ e acompanhada pelo recrudescimento dos processos de voçorocamento que afligem toda a depressão;

- as planícies de inundação holocênicas são ocupadas por sequências ordenadas de cascalhos, areias e, às vezes, argilas orgânicas, enquanto as calhas continuem seu aprofundamento no assoalho rochoso.

Os eventos relatados foram datados de um ponto de vista apenas relativo, apoiando-se em fatos devidamente datados em outras partes do país. O primeiro dado de geocronologia absoluta de eventos pleistocênicos nesta região, foi fornecido por Turcq et al. (1987) que dataram um terraço do córrego da Sepultura (18³5'S-4350’W) em 31.950anosAP (datação por radiocarbono de madeira fossilizada em argilas orgânicas). O local dista $25 \mathrm{~km}$ a sul das sequências estudadas por Saadi \& Valadão (1987). O material analisado corresponde aos alúvios que entulharam os vales após a segunda fase de dissecação fluvial, confirmando sua atribuição ao Pleistoceno Inferior. Ignorando, aparentemente, esses trabalhos anteriores, Augustin (1994) fornece nova confirmação dessa idade, com datações (também por radiocarbono) em sequência muito parecida com as de Saadi \&Valadão (1987) e localizada próximo destas $\left(18^{\circ} 25^{\prime} 38^{\prime \prime S}-43^{\circ} 49^{\prime} 05^{\prime \prime W}\right)$. A sequência em questão apresenta, na base, uma fase basicamente aluvial composta por duas camadas de argilas orgânicas e uma central arenosa. $\mathrm{O}$ conjunto foi fossilizado por $1,8 \mathrm{~m}$ de colúvios argilo-silto-arenosos. As camadas orgânicas forneceram idades respectivas de 38.750 $\pm 5.100 /$
3.100anosAP, para a inferior, e 17.190 \pm 720 anosAP, para a superior.

\section{Na Borda Leste do Planalto}

Machado et al. (1986), no quadro das atividades de Trabalho Geológico de Graduação do Curso de Geologia (IGC/UFMG), dedicaram, sob orientação de A.Saadi, um capítulo específico à evolução quaternária das bacias dos rios Parauninha e Lambari, afluentes do rio Santo Antônio (bacia do rio Doce) a NW de Conceição do Mato Dentro.

Os vales desses rios apresentam planícies com formas amendoadas, localizadas em depressões escavadas ao pé das frentes de empurrão, de direção NNW-SSE e vergência para $\mathrm{W}$, que controlam escarpas voltadas para W, com alturas superiores a 500m (Serra de Ouro Fino, ou da Penha, ou da Gurita). Os vales são altimetricamente escalonados, sendo que a planície do rio Parauninha apresenta desnivelamento entre as partes montante e jusante marcado por uma queda encachoeirada superior a 100m (Cachoeira da Fumaça, próximo a Candeias).

A análise de vários perfis transversais nos dois vales resultou nas seguintes conclusões:

— existem 3 níveis deposicionais aluviais, escalonados, de expressão regional: um nível de várzea arenoso e 2 níveis de terraços com seixos de quartzo arredondados, sendo que as alturas destes últimos variam de $2 \mathrm{~m}$ e $5,5 \mathrm{~m}$, nas planícies mais elevadas, para $6 \mathrm{~m}$ e 12-15m, na planície mais baixa;

- ocorreram 2 a 3 fases de coluvionamento, sempre precedidas por eventos denudacionais marcados por stone lines;

- no vale do rio Parauninha, a parte da planície localizada a montante da cachoeira corresponde a um bloco basculado para NW, por uma falha de direção SWNE. Consequentemente, a soleira criada pela referida escarpa bloqueou a dissecação, gerando um soterramento da sequência do $1^{\circ}$ terraço de cascalho pelas areias do nível de várzea.

A área marginal a esta borda do planalto constitui um mega-anfiteatro onde se alojam as bacias de quatro dos maiores afluentes do rio Doce. Esta feição (caracterizada por Saadi 1991, como "Anfiteatro Escalonado da Margem Esquerda do Rio Doce”) é composta por compartimentos morfotectônicos delimitados por falhas NE-SW, tectonicamente escalonados de NW para SE (em sentido decrescente) e basculados em direção NW (Fig. 4 e 10).

O primeiro degrau a margear a Serra do Espinhaço segmento Serro-Virginópolis - apresenta morfologia de colinas baixas e suaves, com a seguinte organização: a) topos residuais a $960 \mathrm{~m}$ portam carapaça ferruginosa com $2 \mathrm{~m}$ de espessura; b) a linha de topos média (850m) apresenta colúvios areno-argilosos sobre stone line composta por fragmentos da carapaça ferruginosa; c) as encostas exibem sequência aluvial de planície, provavelmente do Pleistoceno Superior, com $20 \mathrm{~m}$ de espessura; d) os fundos de vales atuais (cota média de $800 \mathrm{~m}$ ) são totalmente afogados por extensas planícies, frequentemente pantanosas. 
O piso morfotectônico da área marginal é constituído pelo vale do rio Doce, que se situa na cota $300 \mathrm{~m}$, na região dos lagos de Ipatinga-Timóteo. A formação destes, inicialmente considerada como resultado de oscilações climáticas (Pflug 1969, Meis 1978), iniciou-se no Holoceno, em torno de 9.500 a 9.000 anos AP (vide Turcq et al. 1994). No entanto, Barbosa \& Kohler (1981) sugeriram causas ligadas a um rifteamento "regional localizado" de direção N-S, e Saadi (1991) propôs um controle tectônico associando também falhas E-W.

\section{Na Borda Oeste do Planalto}

A borda oeste carece ainda de trabalhos aprofundados. Existem apenas informações esparsas, que, no entanto, convergem em direção a um reconhecimento da importância da atividade neotectônica.

Adotando a premissa da origem tectônica da escarpa (Brajnikov 1947, King 1956), Abreu (1982) descreve a concentração de feições morfotectônicas na parte do Planalto de Diamantina drenada pelos rios sanfranciscanos, tais como: escarpas com facetas trapezoidas, desnivelamento de superfícies de aplainamento "quebradas e basculadas", "transcorrências de blocos", cones de dejeção associados aos setores mais fraturados da bacia do rio Pardo Pequeno.

As jazidas de manganês formadas sobre a superfície de 1.000 e $1.100 \mathrm{~m}$ foram investigadas (junto com a geóloga Elba Caldeira Leite), na bacia do rio Pardo Grande, $10 \mathrm{~km}$ a norte de Conselheiro Mata. Nelas levantou-se falhamentos recentes nas direções N0-10E e N35-75E. Em ambas as direções, o caráter das falhas é predominantemente normal, com algumas transcorrências. Falhamentos de idade recente em condições semelhantes (jazidas de manganês da Serra do Cipó) foram também relatados por Dossin \& Dardenne (1984). Um pouco ao sul da jazida referida, na entrada do canyon do rio Pardo Grande, a capa das camadas de quartzitos exibe uma rede de falhas e fraturas, com as direções N60E (a mais marcada, correspondendo à direção local do canyon), N30W (a mais frequiente, correspondendo ao trecho inferior do canyon), N20E e NS.

A área marginal a esta borda é constituída pela depressão drenada pelos rios Jequitaí e Curimataí, entre as serras de Minas e do Cabral, e adaptada a uma ondulação sinclinal. Transecto morfopedológico realizado por Augustin et al. (1994), entre a Serra do Cabral e a Serrinha, assinala a existência de um patamar a $800 \mathrm{~m}$ e leques colúvio-aluviais na base da encosta. Valadão et al. (1994) descreve uma cascalheira com elementos quartzosos e quartzíticos (esp. $=50 \mathrm{~m})$, no topo da Serrinha. As definições da localização da área fonte, na Serra do Cabral, e da idade, no Cretáceo Sup., não são ainda sustentadas por argumentos convincentes. Este depósito pode, muito bem, ter idade mais nova e origem na Serra de Minas.

A sul da Serra do Cabral, a área marginal é constituída por compartimentos morfotectônicos, formando patamares escalonados em altitudes decrescentes para oeste, com superfícies inclinadas de W para E (Fig. 10), sendo controlados por falhas de empurrão NNW-SSE (Saadi 1991, 1993b). Na base da escarpa da Serra do Cipó, ocorrem falhamentos pleistocênicos normais, inversos e transcorrentes (E-W), próximo a Cardeal Mota, e normais afetando os terraços do rio das Velhas, entre Presidente Juscelino e Santo Hipólito.

\section{Formas e depósitos no Planalto Setentrional e suas margens}

\section{As superfícies de aplainamento}

Num enfoque regional, King (1956) destaca a ocorrência de 4 ciclos de denudação, resultando na "Superfície Pós-Gondwana" representada pelo topo da Serra da Bocaina (1.300m), a "Superfície Sul-americana" representada pelas chapadas superiores $(800-900 \mathrm{~m})$, a "Superfície Velhas" representada por patamares de origem fluvial (500-700m) e os vales do "Ciclo Paraguaçu”, abaixo da cota $300 \mathrm{~m}$. O escalonamento altimétrico dos níveis de denudação resultaria de soerguimento epirogênico de alcance supra-regional.

Barbosa (1960) defende a ocorrência de 3 ciclos de denudação para o Médio Jequitinhonha, representados pela "Superfície das Chapadas" (Paleogeno, 850m), o "Ciclo Pós-Chapada" (Neogeno, 350m) e o "Ciclo Atual". A "Superfície das Chapadas" corresponderia à "Superfície Sulamericana" e teria sido preservada da destruição total pelo alçamento tectônico, enquanto os dois últimos eventos seriam apenas duas fases de um só ciclo.

Concordando com King (1956), este autor interpretou a justaposição da "severa horizontalidade" do Alto Jequitinhonha com a imponente dissecação do médio vale, como sinal de extrema juventude do Ciclo PósChapada.

Rennó (1974) definiu uma série de 5 ciclos denudacionais para o NE do estado. Os altos da Serra da Bocaina corresponderiam à "Superfície Pré-Cretácica" (Superfície Gondwana). A "Superfície Pós-Cretácica 1" (Pós-Gondwana) não ocorreria na região. A "Superfície Pós-Cretácica 2" (Sulamericana), representada pelas chapadas superiores, teria tido seu período de elaboração estendido até o Plioceno, quando teria sido basculada para leste. A "Superfície Vacaria", confinada à depressão granítica da janela estrutural de Itacambira-Espinosa. Sua gênese resultaria da diferenciação litológica e sua idade seria do intervalo entre os ciclos "Pós-Cretácico 2" e "Pleistocênico". Este último, correspondente ao Ciclo Velhas, seria o responsável pela elaboração das depressões de Araçuaí e do rio Salinas.

A série de ciclos definidos por King (1956) foi considerada pertinente no trabalho do CETEC (1980), sendo o conjunto de chapadas e patamares definido como "áreas aplainadas com zonas dissecadas", resultando do "Ciclo Sulamericano", para os níveis de 800-900m, e do "Ciclo Velhas", para os níveis de 500-700m.

Um segundo compartimento, denominado "Serras, Patamares e Escarpas do Espinhaço" e constituído por uma "sucessão de superfícies de aplainamento 
escalonadas, com escarpamentos orientados por fraturas", englobaria o alinhamento meridiano das serras da Bocaina e Geral, cujos topos (1.200-1.300m) seriam testemunhos do "Ciclo Pós-Gondwana".

Este trabalho enfatiza muito a "influência da geologia sobre o relevo", ressaltando as quedas brutais afetando o perfil do rio Jequitinhonha em Salto da Divisa e Terra Branca e a preservação do gradiente elevado entre Virgem da Lapa e o nível de base local da Ponte de Caçaratiba. São fatos que apoiam a interpretação de King (1956), retomada por Barbosa (1960), sobre a juventude da dissecação do Ciclo Pós-Chapadas.

Do conjunto desses trabalhos sobressaem alguns pontos de convergência. O primeiro deles é o consenso de que o topo das chapadas representa um nível de aplainamento Sulamericano de King (1956). O segundo é a inclinação, de origem tectônica, dessa superfície para leste. O terceiro é o reconhecimento, em Barbosa et al. (1980) da interpretação tectônica dos caimentos convergentes dos planaltos do Jequitinhonha e do Araçuaí, em direção ao eixo submeridiano do rio Araçuaí (King 1956).

No entanto, nota-se que o consenso sobre a juventude dos eventos denudacionais posteriores ao Ciclo Sulamericano, nem sempre está de acordo com as idades propostas. Só a cronologia adotada por Rennó (1974), admitindo que o desenvolvimento deste se estendeu até o Plioceno, apresenta uma coerência interna.

Ao concordar que o aplainamento "oligocênico" afetou, também, o pacote sedimentar da Formação São Domingos (Pedrosa-Soares 1981), que capeia as chapadas da Depressão do Baixo Rio Araçuaí, os autores acabam atribuindo a estes sedimentos uma idade paleogênica. Em contraposição a isto, Saadi (1991) demonstrou que a Formação São Domingos fossiliza uma porção da Superfície Sulamericana, que foi rebaixada tectonicamente para formar o piso do Graben de Virgem da Lapa. Os sedimentos possuem, consequentemente, a idade pliocênica do Grupo Barreiras (nesta latitude), e seus topos representam muito mais uma superfície estrutural sustentada por uma espessa carapaça ferruginosa. Por outro lado, há de alertar sobre o tamanho da ousadia que conduz a interpretar uma única linha de crista como testemunho de uma superfície de aplainamento de alcance regional. Acredita-se que a Serra da Bocaina só deve constituir um relevo residual, do tipo monadnock, do aplainamento sulamericano.

\section{Formas e depósitos do Planalto}

A geomorfologia do Planalto Setentrional foi investigada por Saadi et al. (1991b), no âmbito dos estudos de viabilidade da Unidade Hidrelétrica de Irapé (logo a jusante da confluência dos rios Jequitinhonha e Itacambiruçu), realizados para a CEMIG (Fig. 9).

Estes definiram 4 grandes tipos de unidades de relevo.

O "tipo serrano" corresponde ao "Monadnock Central" (quartzitos e conglomerados), entre as cotas 950 e $1.467 \mathrm{~m}$ (Foto 3 ), sendo composto pelas cristas assimétricas dos fronts de empurrão (serras Geral e da Bocaina) e pequenos platôs, alguns constituindo prováveis klippes (Morro do Chapéu).

O "tipo chapadas" agrega as unidades de relevo do plano fundamental (xistos, com quartzitos subordinados), suavemente inclinadas e/ou onduladas, entre as cotas 750 e $1.000 \mathrm{~m}$ (Foto 3).

As situadas entre 800 e $1.000 m$ (Superfície Sulamericana), se diferenciam por suas coberturas superficiais. Na margem esquerda do rio Jequitinhonha (ex.: Chapada do Cemitério), elas são encobertas por um lençol formado por até $90 \%$ de areias quartzosas médias e bem classificadas, espalhado a partir dos relevos quartzíticos. Na margem direita (ex.: Chapada de Acauã), ocorre uma cobertura argilo-silto-arenosa a arenoargilosa preenchendo paleo-depressões fluviais, com espessura "visível" de até $5 \mathrm{~m}$. Numa dessas, localizada próximo a Acauã (Foto 7), no meio e na base das areias ocorrem seixos e blocos de quartzo, organizados em lençóis e/ou lentes, bem como seixos de quartzo arredondados. Esta cobertura representa um lençol colúvio-aluvionar, desenvolvido consecu-tivamente à dissecação da superfície terciária, e que pode atingir espessura decamétrica, conforme dados de poços furados pela COPASA.

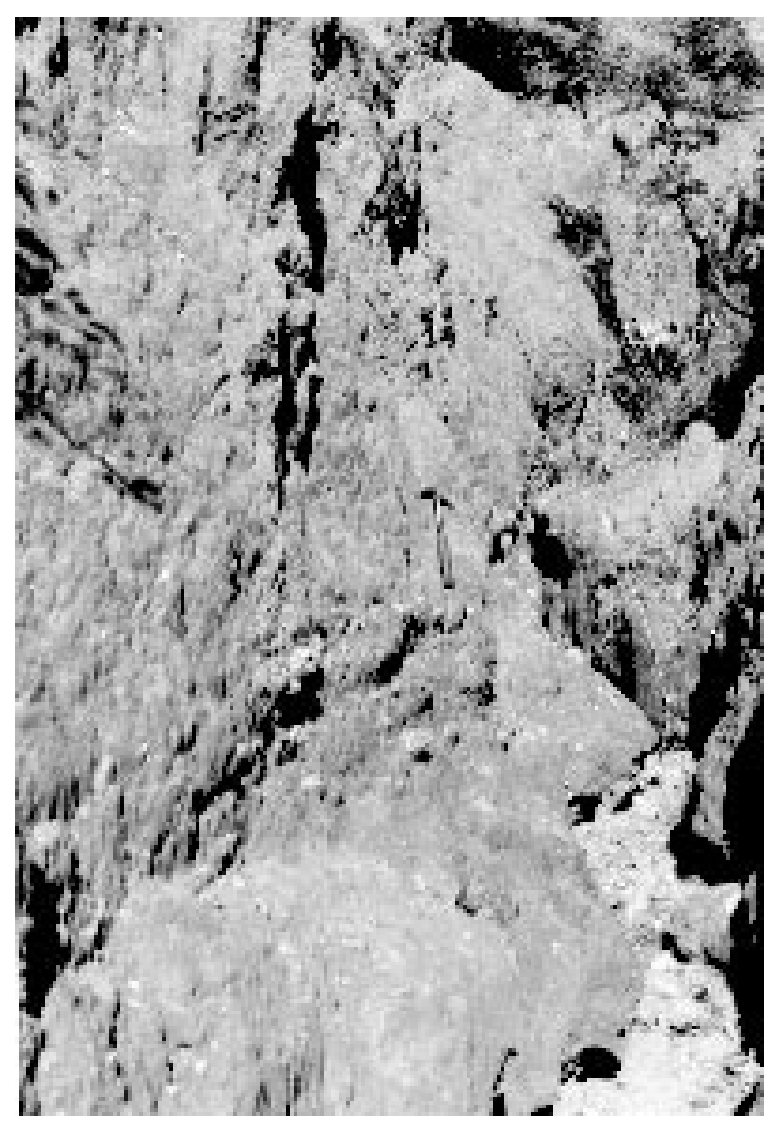

Foto 7: Cobertura colúvio-aluvial da Chapada de Acauã (superfície paleogênica no Planalto

Setentrional): areias com intercalação de lentes de cascalho e seixos de quartzo.

Photo 7: Colluvial-alluvial cover of the Chapada de Acauã (paleogenic surface in the Planalto

Setentrional): fine sand with intercalation of quartzpebble-gravel lenses. 


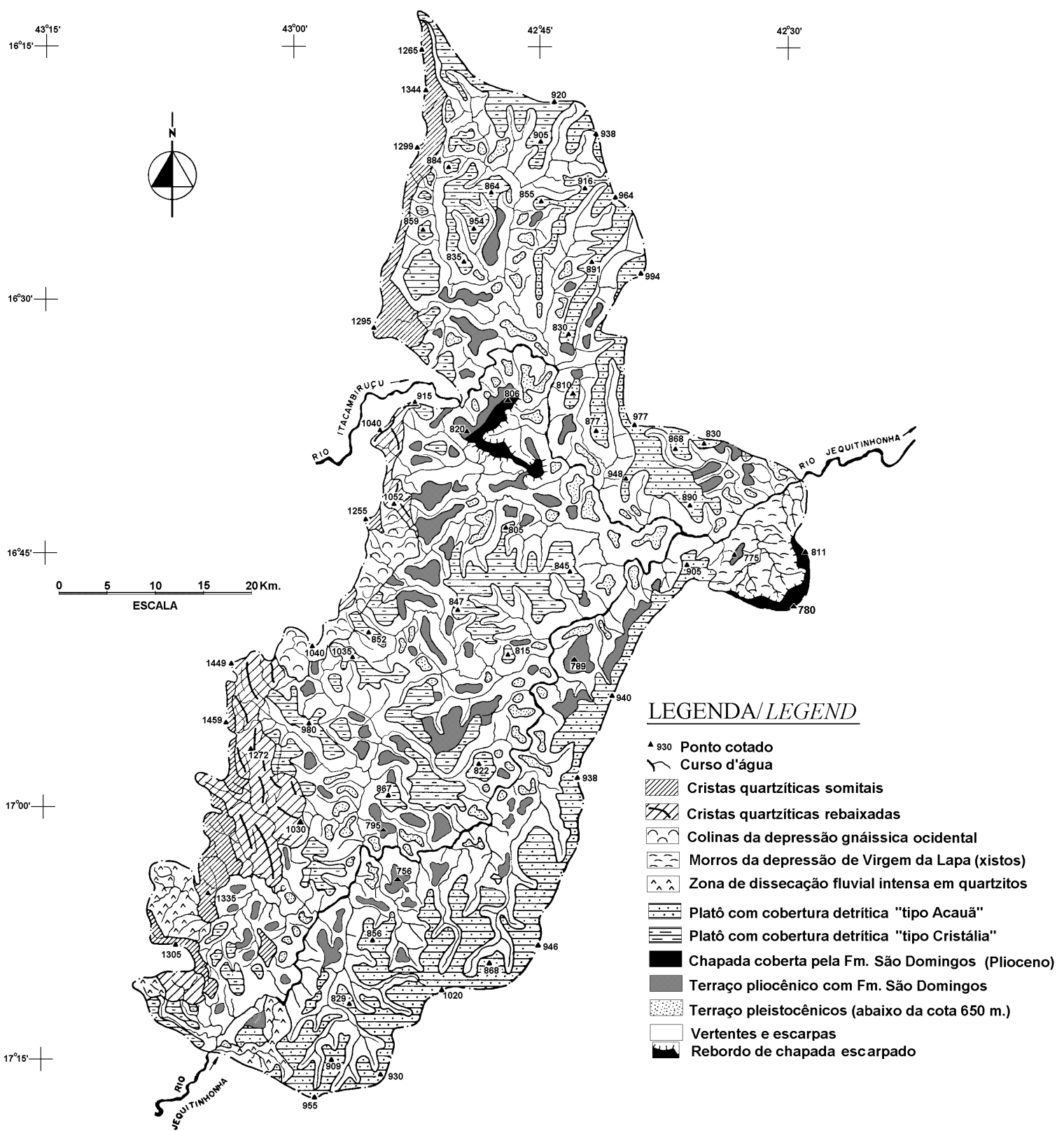

Figura 9: Mapa geomorfológico da porção centro-leste do Planalto Setentrional. (modificado de Saadi et al. 1991)

Figure 9: Geomorphological map of the central-eastern part of the Planalto Setentrional.

Augustin et al. (1994) afirma, com base na análise de um único perfil com espessura de $1,6 \mathrm{~m}$, localizado na borda sul do planalto, que essa cobertura reflete apenas uma pedogênese holocênica sobre saprolitos com idades entre 10 e 120 milhões de anos (?).

Entre 750 e $800 \mathrm{~m}$, ocorrem patamares cobertos por espessuras variáveis de sedimentos da Formação São Domingos, correspondendo a restos do Terraço Pliocênico dos rios Itacambiruçu e Jequitinhonha, frequentemente protegidos por carapaça ferruginosa.

Entre os alinhamentos de relevos quartzíticos, a Depressão de Itacambira-Espinosa (Superfície Vacaria de Rennó 1974) exibe o "tipo colinas" convexas sobre gnaisses arqueanos, com topos entre 900 e $1.000 \mathrm{~m}$ e alturas de 150 a 250m. Como na Depressão de Gouveia, uma importante erosão é comandada por voçorocamento.

Entre as cotas 350 e $750 \mathrm{~m}$, desenvolvem-se as unidades de "tipo vales e terraços quaternários". As vertentes são convexas com declividade média de 20$50 \%$ na parte superior e $50-100 \%$ nos fundos de vales, resultado do acentuado aprofundamento mais recente da rede de drenagem. Na parte superior, foram identificados 3 níveis de terraços com seixos e blocos de quartzo perfeitamente arredondados: $1^{\circ}, 2^{\circ}$ e $3^{\circ}$ Terraço Pleistocênico (Nível Superior) em posições respectivas de altitude/altura de $650 \mathrm{~m} / 300 \mathrm{~m}, 600 \mathrm{~m} / 250 \mathrm{~m}$ e $550 \mathrm{~m} /$ $200 \mathrm{~m}$. Na parte inferior das vertentes, ocorrem estreitos patamares, correspondendo aos testemunhos de Terraços Pleistocênicos Intermediários. Não foram, no entanto, identificados detalhadamente na época dos levantamentos de campo, por não apresentarem utilidade específica para o empreendimento proposto. No fundo dos vales relativamente alargados, ocorre um Terraço Pleistocênico Inferior geralmente desfigurado 
pela garimpagem, bem como inúmeras barras arenosas muito instáveis.

Entre Posses e Caçaratiba, a extrema dissecação, caracterizada por importante densidade e encaixamento dos vales, assinala a atividade da frente de dissecação bloqueada pela soleira quartzítica. A montante de Caçaratiba, não existem informações suficientemente fiéis.

\section{A Borda Leste do Planalto}

A borda leste já foi descrita como um escarpamento controlado por falhamento normal neocenozóico, na porção meridional (Pedrosa Soares \& Saadi 1989), e pela Falha de Taiobeiras, no resto de sua extensão.

A área marginal da borda leste é mais rica do ponto de vista geomorfológico. Saadi (1991) descreveu esta área como composta por (Fig. 10):

a - "Depressão do Baixo Rio Araçuaî", caracterizada como graben pliocênico de direção NE-SW, hoje composta por chapadas com altitudes decrescentes de sul $(830 \mathrm{~m})$ para norte $(750 \mathrm{~m})$ e pelos vales dos rios Araçuaí e Jequitinhonha, que confluem na cota $300 \mathrm{~m}$. Possuem caráter de tabuleiros, pois são capeadas pos sedimentos pliocênicos da Formação São Domingos. Entre Virgem da Lapa e Araçuaí, os topos de colinas moldadas nos xistos do Grupo Macaúbas, na cota 650m, correspondem à Superfície Sulamericana exumada, por remoção da capa sedimentar (Foto 4).

b - "Planalto Basculado da Margem Direita do Rio Araçuaî", composto por retalhos de chapadas alongados e inclinados de SSE (1.200m) para NNW (800m), configurando um basculamento tectônico, com inclinação de $0,8 \%$ da Superfície Sulamericana em direção ao graben;

c - "Depressão do Rio Salinas" cuja direção é controlada pela Falha de Taiobeiras, desenvolvida abaixo da cota $500 \mathrm{~m}$, em meio a chapadas com inclinações suavemente convergentes, entre cotas de 1.000 e $700 \mathrm{~m}$.

Os sedimentos da Formação São Domingos, que preenchem o Graben de Virgem da Lapa, foram relatados, pela primeira vez, em Hartt (1870), como equivalentes continentais dos sedimentos costeiros (hoje Grupo Barreiras), sendo sua posição em topos de chapadas devida a movimentos tectônicos. Guimarães (1951) atribui essa "Formação Terciária" a lagos de dimensões regionais, que teriam margeado a Serra do Espinhaço. King (1956) adota a idéia do lago, relacionando os sedimentos com a elaboração da Superfície Sulamericana. Estado da arte e discussão completa sobre o assunto encontram-se em Saadi (1991) e Saadi \& Pedrosa-Soares (1991).

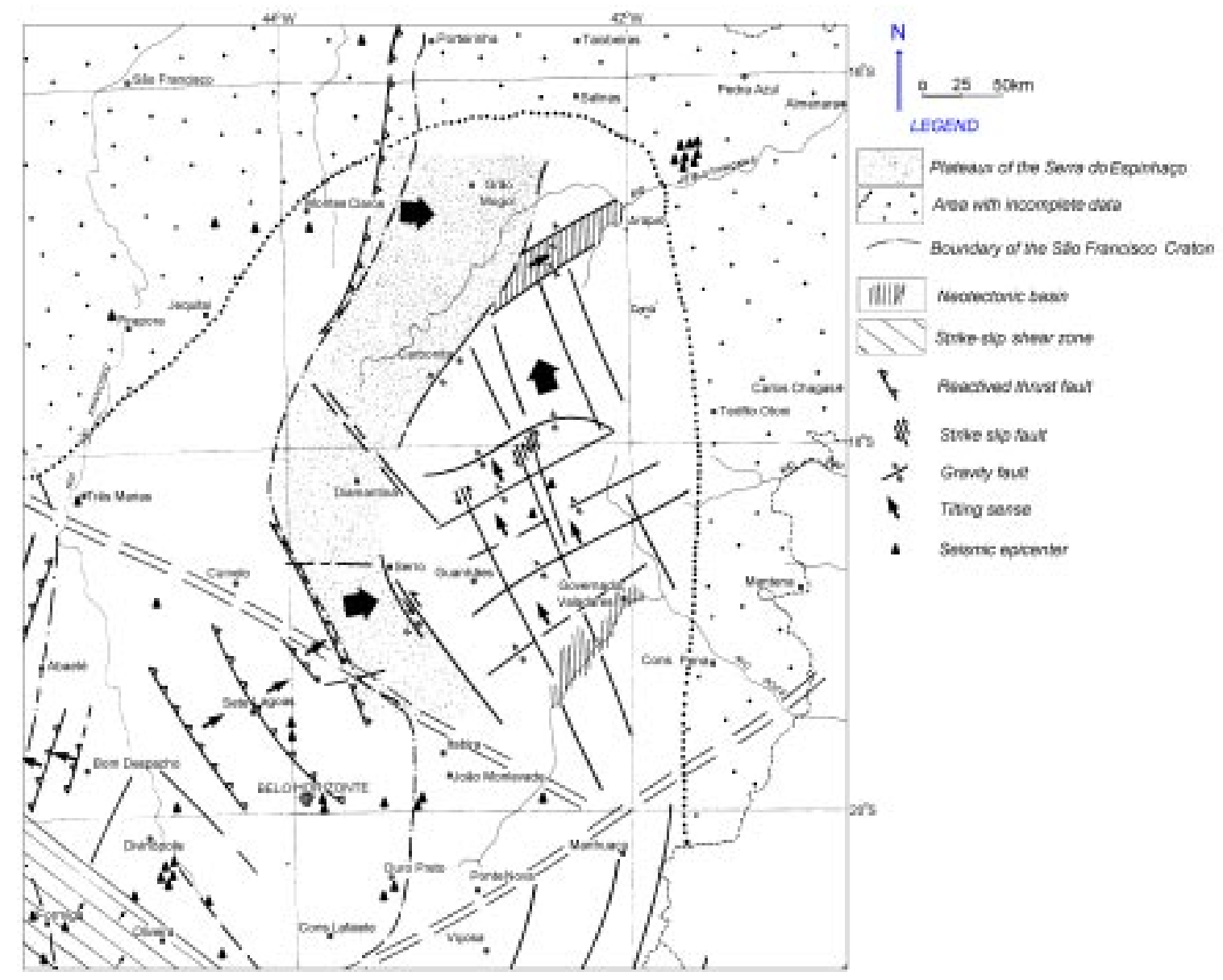

Figura 10: Mapa morfotectônico da borda leste do Cráton do São Francisco (fonte Saadi 1991). Figure 10: Morphotectonic map of the eastern border of the São Francisco Craton. 
A bacia correspondente estende-se, ao sul, entre o rio Araçuaí e as localidades de Turmalina, Minas Novas, Chapada do Norte, entre outros. Ao norte, nas chapadas a oeste de Rubelita e, a leste, nas chapadas entre os rios Jequitinhonha e Araçuaí. Entre Minas Novas e Turmalina, acima da cota 750m, ocorre fácies argilosa, tipicamente lacustre, sobre blocos e seixos de quartzo, sendo o conjunto sotoposto a fácies fluviais arenosas. A base da sequência é afetada por falhas normais de direção N30-50E e mergulho para SE. Em torno de Turmalina, uma sequência com espessura de $80 \mathrm{~m}$ e base na cota $750 \mathrm{~m}$, apresenta fácies de canal e planície aluviais entremeadas por fácies depositadas por correntes de densidade. Esta é afetada por falhas normais e transcorrentes de direção NW-SE e N-S (Foto 8). No morro que sustenta a torre de TV de Chapada do Norte (700-750m), afloram fácies aluviais rudáceas e arenosas, com falha E-W, transcorrente destrógira.

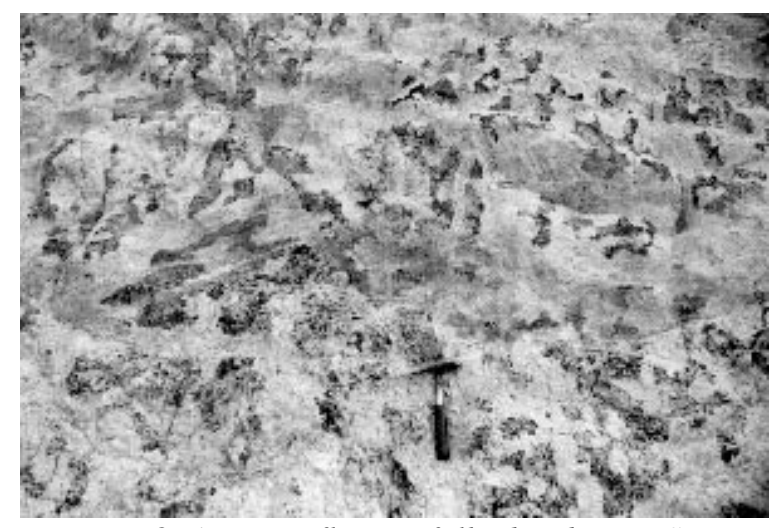

Foto 8: Arenitos fluviais falhadas da Fm. São Domingos, próximo a Turmalina.

Photo 8: Faulted fluvial arenites of the São Domingos Formation, near Turmalina.

Em Virgem da Lapa, a base da mesma sequência desce para a cota $650 \mathrm{~m}$, enquanto a espessura aumenta para $100 \mathrm{~m}$, ocorrendo falhamentos NE-SW, NW-SE e N-S. Nos relevos que dominam a periferia da bacia (escarpa da Chapada de Acauã e topos das chapadas orientais) ocorrem canais suspensos, preenchidos por fácies de leques aluviais.

No interior do Planalto Setentrional, ocorrem fácies tipicamente fluviais compostas por camadas de seixos arredondados de quartzo, com estratificações cruzadas acanaladas, e arenitos finos a médios. Essas ocorrências possuem dois posicionamentos distintos. O mais regular é representado pelo Terraço Superior dos rios Itacambiruçu e Jequitinhonha, formando degrau em altitudes que variam de $750 \mathrm{~m}$ (jusante) a $800 \mathrm{~m}$ (montante), ou seja, em altura média de $360 \mathrm{~m}$. As ocorrências sobre as chapadas denunciam uma inclinação de W para E: 1.000m próximo a Grão Mogol, 800 e 750m na Chapada de Santa Rosa (margem direita do rio Itacambiruçu), 750m em Leliveldia e 650m acima de Virgem da Lapa.

\section{A Borda Oeste do Planalto}

Nesta borda, a escarpa domina, frequentemente, patamares intermediários antes de atingir a depressão da bacia do rio São Francisco, ocupada por relevo ligeiramente ondulado nos filitos e calcários do Grupo Bambuí. Na latitude de Francisco Sá, entre o rebordo da escarpa $(1.050 \mathrm{~m})$ e a depressão $(690 \mathrm{~m})$, ocorrem vales suspensos, entre 1.000 e $900 \mathrm{~m}$, e um nível intermediário de colinas, a 770-800m. Mais para oeste, ocorrem platôs baixos, coroados por sedimentos cretáceos.

Esta borda foi considerada por King (1956) como escarpa de falha limitando uma fossa tectônica cenozóica. Os autores que lhe sucederam adotaram, quase unanimamente, esta interpretação.

\section{DISCUSSÃO E INTERPRETAÇÃO}

Os dados e informações apresentados mostram que a investigação geomorfológica da Serra do Espinhaço, foi caracterizada por trabalhos ao mesmo tempo muito diversificados pelos enfoque e profundidade, e desconectados espacialmente. A análise dos resultados desses será conduzida no sentido de, num primeiro momento, estabelecer uma síntese da cronologia da formação do relevo, para, em seguida, discutir as partes respectivas das influências exercidas pelos fatores climático e tectônico.

\section{Cronologia dos eventos denudacionais e deposicionais}

A sucessão de eventos denudacionais e deposicionais que caracterizou o ritmo da evolução geomorfológica da Serra do Espinhaço, em Minas Gerais, pode ser definida com base na coordenação dos eventos de aplainamentos regionais, ocorridos durante o Mesozóico-Terciário, e dos eventos quaternários de dissecação e entulhamento dos vales.

No Quadro 1 é apresentada uma síntese das opiniões emitidas sobre a cronologia da denudação de longo prazo.

A primeira observação que se impôs é a unanimidade sobre o limite Paleoceno-Eoceno, como marco cronológico entre os eventos denudacionais cenozóicos, relativamente bem testemunhados, e os mais antigos (Gondwana e Pós-Gondwana de King 1956), definidos a partir de especulações altimétricas. A comprovação da ocorrência destes últimos é comprometida pela fragilidade dos argumentos apresentados, os quais se resumem, geralmente, à coordenação de alguns topos de morros e cristas em altitudes que podem variar de centenas de metros. A indefinição com relação aos testemunhos desses eventos, fica ainda mais patente no caso do Planalto Setentrional.

Ao observar a maior concentração dos presumíveis remanescentes da "Superfície Pós-Gondwana (King 1956)/Nível 3 (Abreu 1982)" no Planalto de Diamantina, é grande a tentação de interpretar esta área como um Primärrumpf (Penck 1924), ou seja o resto de uma superfície primitiva, preservado graças ao alçamento tectônico. Quatro outros argumentos militam 


\begin{tabular}{|c|c|c|c|c|c|c|c|}
\hline \multirow[b]{2}{*}{ IDADE } & \multicolumn{3}{|c|}{ PLANALTO MERIDIONAL } & \multicolumn{2}{|r|}{ PLANALTO } & \multicolumn{2}{|l|}{ SETENTRIONAL } \\
\hline & $\begin{array}{l}\text { King } 1956 \\
\text { (1) }\end{array}$ & $\begin{array}{l}\text { Abreu } 1982 \\
\text { (2) }\end{array}$ & $\begin{array}{c}\text { Saadi \& } \text { Valadão } \\
1987 \text { (3) }\end{array}$ & $\underset{(4)}{\text { King }} 1956$ & $\begin{array}{c}\text { Barbosa } \\
(5)\end{array}$ & $\underset{(6)}{\text { Rennó }} 1974$ & $\begin{array}{l}\text { Saadi et al. } 1991 \\
\text { (7) }\end{array}$ \\
\hline \multirow{2}{*}{\begin{tabular}{|l} 
Holoceno \\
Pleistoceno
\end{tabular}} & & & Várzeas & & & & Várzeas \\
\hline & Paraguaçu & & $\begin{array}{c}\text { Terraços } \\
950-1.000 \mathrm{~m}\end{array}$ & Paraguaçu $<300 \mathrm{~m}$ & Ciclo Atual & Ciclo Pleistocênico $<800 \mathrm{~m}$ & Terraços $\quad 300-650 \mathrm{~m}$ \\
\hline Plioceno & Velhas & $\begin{array}{c}\text { Nível } 1 \\
750-800 \mathrm{~m}\end{array}$ & $\begin{array}{c}3^{0} \text { nível } \\
1.050-1.100 \mathrm{~m}\end{array}$ & Velhas $500-700 \mathrm{~m}$ & \multirow[t]{2}{*}{ Ciclo Pós-Chapadas } & Superfície Vacaria (local) & Patamar $750 \mathrm{~m}$ \\
\hline Mioceno & & & \multirow[t]{2}{*}{$2^{0}$ nível } & & & \multirow{2}{*}{ Superfície Pós-Cretácica 2} & \multirow[t]{2}{*}{ Chapadas } \\
\hline Oligoceno & Sulamericana & Nível 2 & & Sulamericana & \multirow[t]{3}{*}{ Superfície das Chapadas } & & \\
\hline Eoceno & $1.100-1.200 \mathrm{~m}$ & $1.000-1.100 \mathrm{~m}$ & $1.250-1.300 \mathrm{~m}$ & $800-900 \mathrm{~m}$ & & $900-1.000 \mathrm{~m}$ & $800-1.000 \mathrm{~m}$ \\
\hline Paleoceno & Pós-Gondwana & Nível 3 & \multirow{4}{*}{$\begin{array}{c}11^{0} \text { nível } \\
>1.300 \mathrm{~m} \quad \text { (?) }\end{array}$} & Pós-Gondwana & & Superfície Pós-Cretácica 1 & \multirow{5}{*}{ ? } \\
\hline Cretáceo Sup. & $1.400 \mathrm{~m}$ & $1.200-1.400 \mathrm{~m}$ & & $1.300 \mathrm{~m}$ & & & \\
\hline Cretáceo Méd. & Gondwana & & & & & & \\
\hline \multirow[t]{2}{*}{ Cretáceo Inf. } & $1.800 \mathrm{~m}$ & & & & & & \\
\hline & & & & & & $\begin{array}{c}\text { Superfície Pré-Cretácica } \\
1.300 \mathrm{~m}\end{array}$ & \\
\hline
\end{tabular}

Quadro 1: Eventos denudacionais definidos para a Serra do Espinhaço em Minas Gerais.

Table 1: Denudational events defined in the Serra do Espinhaço, in the state of Minas Gerais. NOTA: (1) Serra do Cipó, (2) Planalto de Diamantina, (3) Depressão de Gouveia, (4) Planalto Setentrional, (5) Médio Jequitinhonha, (6) Nordeste de Minas Gerais, (7) Planalto Setentrional.

a favor desta interpretação: a) irradiação, a partir desta região, das faixas hipsométricas em sentido decrescente (Fig. 2); b) a região constitui o local de irradiação centrífuga da drenagem regional (Fig. 5); c) por consenso dos autores, a região representa o local de maior soerguimento tectônico, durante o Cenozóico; d) não se encontram neste planalto depósitos correlativos de eventos erosivos de extensão regional.

O primeiro nivel de aplainamento consensualmente reconhecido é o correspondente ao evento paleogênico, ocorrido no período Eoceno-Oligoceno (King 1956, Abreu 1982) ou Eoceno-Mioceno (Rennó 1974, Saadi \& Valadão 1987 e Saadi et al. 1991). As divergências sobre sua altitude no Planalto Meridional são compreensíveis, visto a possibilidade de erros de avaliação decorrentes da topografia muito irregular e da baixa qualidade dos mapas topográficos, que comportam inúmeros erros de cotação. No Planalto Setentrional, no entanto, onde a morfologia é muito mais regularizada, este tipo de desacordo reflete claramente um problema de interpretação. King (1956) e Barbosa (1960) adotaram cotas mais baixas por considerarem que esta superfície nivela-se com os topos das chapadas capeadas pela Formação São Domingos. Esta seria, consequentemente, mais velha ou, no mínimo, contemporânea da superfície, representando seus depósitos correlativos. Ao adotarem as cotas das chapadas mais elevadas, Rennó (1974) e Saadi et al. (1991) consideram a idade pliocênica da Formação São Domingos, cujo topo passa a constituir uma superfície estrutural controlada por suas camadas horizontais. Neste caso, a superfície paleogênica está fossilizada por esses sedimentos, no interior do Graben de Virgem da Lapa (Saadi 1991), reaparecendo, quando exumada (Foto 4), entre as cotas $750 \mathrm{~m}$ (Turmalina) e $650 \mathrm{~m}$ (Virgem da Lapa).

O segundo nível de aplainamento cenozóico, consensualmente situado no Plioceno é, também, objeto de divergências. No Planalto Meridional, Saadi \& Valadão (1987) o situaram na altitude em que King
(1956) e Abreu (1982) definiram o nível paleogênico: no topo das colinas da Depressão de Gouveia, em altitude de 1.050-1.100m.

Abreu (1982), no rastro de informações de caráter geral de King (1956), associou o nível pliocênico ao patamar do terraço mais alto do rio Jequitinhonha (750$800 \mathrm{~m})$. No entanto, este patamar só é bem caracterizado quando o vale adentra a Depressão de Couto de Magalhães e o Planalto Setentrional. Desta maneira, há acordo com Saadi et al. (1991), que atribuem sua formação no Planalto Setentrional à adaptação dos vales ao rebaixamento do nível de base do rio Jequitinhonha pela abertura do Graben de Virgem da Lapa. Este patamar, muito bem individualizado pela morfologia, é coberto por alúvios da Formação São Domingos, resultando do afogamento dos vales, uma vez preenchido o graben. Sobre o nível de 1.050-1.100m da Depressão de Gouveia (Saadi \& Valadão 1987) ocorrem sedimentos aluviais semelhantes a esses.

Fato estranho é que King (1956) e, sobretudo, Barbosa (1960) não fazem referência a este patamar no Planalto Setentrional. Ambos atribuem ao Plioceno a elaboração dos vales (quaternários) situados em altitudes inferiores a $700 \mathrm{~m}$.

Sobre os ritmos da evolução geomorfológica durante o Quaternário, as informações sistematizadas são mais raras.

Para o Planalto Meridional, Saadi \& Valadão (1987) e Machado et al. (1986) determinaram, em situações comparáveis - depressões fluviais de Gouveia e da região de Conceição do Mato Dentro, respectivamente - sequências parecidas de níveis fluviais escalonados: nível das várzeas holocênicas entulhadas por aluviões, geralmente arenosos; nível de cascalheira inferior (Pleistoceno Sup.) e nível de cascalheira superior (Pleistoceno Méd.). Nos dois casos, observou-se que: a) cada fase de dissecação foi seguida por um entulhamento aluvial importante dos vales; b) a altura das cascalheiras varia de 5,5 a $15 \mathrm{~m}$, para o nível superior, e de 1 a $6 \mathrm{~m}$, para o nível inferior; c) na 
interface Pleistoceno Superior/Holoceno, instalaram-se duas coberturas coluviais consecutivas, sempre precedidas por fases de remodelação das encostas.

Para o Planalto Setentrional, Saadi et al. (1991) identificam, no mínimo, 4 níveis fluviais escalonados nas encostas dos vales dos rios Jequitinhonha e Itacambiruçu. Além do nível do leito maior, representado por acumulações de seixos de quartzo e areias brancas descaracterizadas pelo garimpo, ocorrem 3 níveis de terraços (em alturas de 300, 250 e 200m, em média) com blocos e seixos de quartzo muito bem arredondados, sotopostos a areias cinzas, cuja idade deve situar-se no Pleistoceno Inferior a Médio. Nos 200 metros que separam o leito do último terraço identificado, devem existir pequenos testemunhos de níveis mais recentes, no entanto ainda não identificados.

Estes dados não devem ser considerados como ilustração de evoluções geomorfológicas diferenciadas dos dois planaltos, mas como testemunhos da variabilidade da dissecação fluvial, em função da importância do curso d'água considerado, de sua posição na hierarquia da rede de drenagem e do contexto morfotectônico. No Planalto Setentrional, estes referemse a vales dos troncos fluviais principais, cujas grandes profundidades representam as consequências do soerguimento global, pois os rios recortam o relevo em toda sua altura e são ligados ao nível de base regional. Quanto ao Planalto Meridional, os dados apresentados expressam apenas a parte da dissecação relacionada com os cursos d'água de ordens intermediárias e/ou inferiores.

Trabalhos posteriores deveriam objetivar o estabelecimento das relações entre o conjunto das sequências, cronologicamente e espacialmente.

Antes de encerrar esta parte da discussão, deve-se ressaltar a importância dos depósitos aluviais, coluviais (ou poligênicos) que recobrem os remanescentes das superfícies de aplainamento terciárias e cuja idade precisa ainda carece de estudo específico:

- sobre os topos de colinas da Depressão de Gouveia, as areias vermelhas, com espessura de $2 \mathrm{~m}$, mais recentes que os depósitos aluviais plio-pleistocênicos e mais velhas que grande parte da dissecação pleistocênica: final do Pleistoceno Superior ou Pleistoceno Médio;

- ainda no Planalto Meridional, sobre o planalto quartzítico (entre 1.000 e $1.400 \mathrm{~m}$ ), a sequência de areias colúvio-aluviais, sobreposta às turfas das depressões de cabeceiras (Foto 6) ou à laterita nodular dos glacis (Foto 5): Pleistoceno ?;

- no Planalto Setentrional, as coberturas colúvioaluviais que recobrem as chapadas, preenchendo as depressões abertas pela dissecação das superfícies terciárias e recobrindo as manchas de Formação São Domingos: final do Pleistoceno Superior ou Pleistoceno Médio.

\section{Os papéis respectivos dos paleoclimas e da tectônica}

A opinião de que a formação do relevo de certa região é o fruto da ação combinada de forças exógenas e endógenas, não obstante seja justa, virou lugar comum e, de certa forma, instrumento puramente literário de quem receia embrenhar-se na tarefa de separar o jóio do trigo. Como no caso das muitas regiões do globo situadas em meio a plataformas "relativamente estáveis", individualizar pormenorizadamente os papéis respectivos dos fatores paleoclimáticos e tectônicos na condução dos processos que modelaram o relevo da Serra do Espinhaço, não constitui tarefa das mais simples. No entanto, o nível de dificuldade ora apresentado não justifica que se ignore o problema, e nem que se postergue o correspondente debate. Debate este, que, no âmbito deste trabalho, basear-se-á nas opiniões publicadas por geocientistas diversos e em novos dados de campo.

No tocante à interveniência dos efeitos dos paleoclimas pleistocênicos, a análise das informações encontradas na literatura deve ser feita em duas escalas.

A primeira, de escala regional, se relaciona com a caracterização "climatogenética" das superfícies de aplainamento. Alguns autores as definem como "pediplanos", denominação esta que situa sua elaboração em ambiente paleoclimático semi-árido, sendo os relevos residuais que permanecem erguidos acima deles legítimos inselbergs, interligados a rampas de pedimentação. Esta opinião expressa por Abreu (1982, p.224) é sintomática do tipo mitigado de argumentação geomorfológica. De fato, ao lado disto, o mesmo autor repete King (1956, p.184), assumindo que a compartimentação fundamental do relevo resultou de várias "fases de reativação tectônica", sendo "as fases de alteração climática" responsáveis pelo aspecto das formas menores. Na realidade, para King (1956), os relevos residuais sobrevivem "à maneira de inselbergs" e aos fatores climáticos, entende-se eventuais mudanças climáticas, foram atribuídos apenas "efeitos, sem maior importância”. Mais adiante, sustentará Abreu (1982, p.234) que "a morfogênese quaternária, marcada pelas oscilações climáticas”, graças a uma certa importância das "condições de sub-úmido à semi-árido", seria a responsável pelo bom "grau de preservação" dos inselbergs e pedimentos.

Saadi \& Valadão (1987a, b), também, na ocasião de precoces investidas em problemas de geomorfologia tropical, enquanto ainda imperavam os modelos climatogenéticos impostos pelas autoridades geomorfológicas da época, cometeram a façanha de reconhecer pediplanos e pedimentos em todas as rampas plio-pleistocênicas da Depressão de Gouveia. Como o tamanho do remorso não justifica o suicídio, há ainda tempo para as devidas retratações.

O que não pode ser ocultado é que as marcas inequívocas do fator climático, impressas nas características sedimentológicas, sobretudo mineraloquímicas, de todos os depósitos cenozóicos, referem-se a ambientes úmidos-quentes, ou seja a climas tropicais úmidos. Os argumentos principais são: a) cascalheiras fluviais com calhaus, seixos e cascalhos de quartzo (petrografia residual), sendo que a presença de outras litologias está sempre associada a transportes curtos e/ 
ou por fluxos densos; b) os argilo-minerais são, via de regra, representados por caulinita e gibsita, em proporções variáveis, associadas a óxidos de ferro e/ ou manganês; c) as acumulações de materia orgânica nos aluviões, ocorrem em locais onde o afogamento da rede de drenagem foi claramente devido à interposição de soleira rochosa e/ou tectônica; d) as formas de relevo são extremamente ubíquas, e não refletem diretamente o produto de um determinado processo, mas o de um conjunto, através de uma série de convergências.

$\mathrm{O}$ fato de não encontrar-se provas indubitáveis de períodos climáticos secos, não significa, no entanto, que não tenham realmente ocorrido nesta parte do escudo brasileiro. Suas marcas podem ter sido apagadas pelo voraz intemperismo dos períodos úmidos.

O papel do fator tectônico foi, por sua vez, sempre realçado nos trabalhos de alcance regional, mesmo se os autores não se empenharam em fornecer argumentos palpáveis. E é efetivamente nesta escala que a organização geomorfológica apresenta o carimbo da instabilidade tectônica, periodicamente renovada, conforme posto, inicialmente, por Hartt (1870), Freitas (1951), Guimarães (1951), Brajnikov (1947) e King (1956) e reafirmado por Barbosa (1960), Abreu (1982), Machado et al. (1986) e Saadi \& Valadão (1987a, b). Mais recentemente, temas diretamente morfotectônicos, relacionados com a Serra do Espinhaço e suas áreas marginais, foram tratados por Pedrosa Soares \& Saadi (1989), Saadi (1991), Saadi \& Pedrosa Soares (1991), Saadi (1993b) e Saadi (1994), desta vez com base em evidências de campo controláveis.

Os efeitos da intervenção da tectônica na morfogênese regional são encontrados: a) no escalonamento de superfícies (Brajnikov 1947, King 1956), e sobretudo terraços fluviais (Saadi et al. 1991); b) nos basculamentos que afetaram várias partes das superfícies de aplainamento (King 1956, Saadi 1991); c) na persistência do vigor das escarpas marginais, independentemente da litologia; d) na organização da

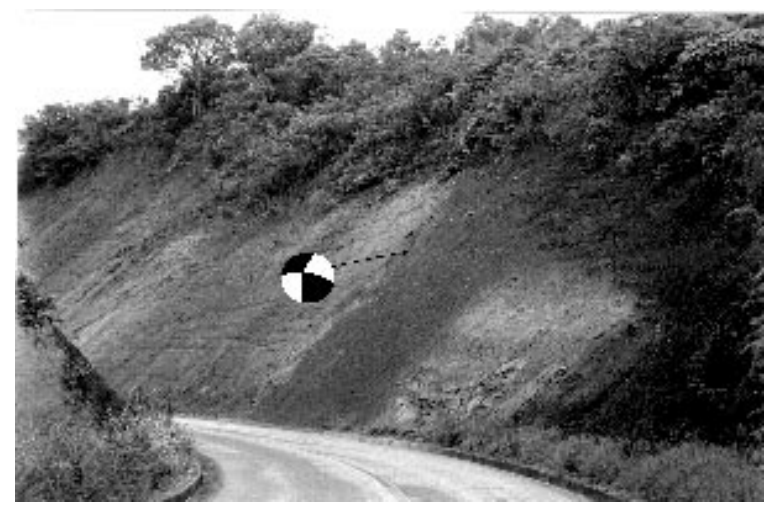

Foto 9: Falha transcorrente pleistocênica separando gnaisses e depósitos coluviais e aluviais cenozóicos, próximo do Serro.

Photo 9: Pleistocenic strike-slip fault, with gneisses to the left and cenozoic colluvial and alluvial deposits to the right, near Serro. rede de drenagem e nas inúmeras capturas intra e interbacias (King 1956, Abreu 1982, este trabalho); e) nas feições morfotectônicas presentes nas áreas marginais, tais como: Graben (Plioceno) de Virgem da Lapa (Saadi \& Pedrosa Soares 1991), graben do Alto Rio do Peixe (Saadi 1991), rift (Pleistoceno Superior-Holoceno) do Médio Rio Doce (Barbosa \& Kohler 1981), vale de falha do Alto Rio Araçuaí (Pedrosa Soares \& Saadi 1989), "Anfiteatro Escalonado da Margem Esquerda do Médio Rio Doce" e blocos basculados situados a oeste da Serra do Cipó (Saadi 1991), entre outros.

Esse conjunto de feições morfotectônicas atesta a recorrência de certa instabilidade tectônica em toda a região, durante toda a era cenozóica. Evidências diretas desta são representadas pelos falhamentos neotectônicos analisados em várias partes da Serra do Espinhaço e suas áreas marginais, por Saadi (1991, 1993b, 1994) e Saadi et al. (1991).

$\mathrm{Na}$ realidade trata-se de um fenômeno normal e extensível a todo o escudo brasileiro, controlado pela instabilidade tectônica global. Este ponto de vista é sustentado, em parte, pelos resultados de determinação dos campos de tensões neotectônicos apresentados por Saadi (1991), os quais são ilustrados junto às Fotos $9 \mathrm{e}$ 10 que retratam observações feitas em barrancos da BR 259, ligando as localidades de Serro e Datas.

$\mathrm{Na}$ Foto 9, trata-se de contato tectônico entre gnaisses alterados e sedimentos mostrando uma gradação de fácies de depósitos de encosta para fácies aluviais, sendo o conjunto fossilizado por uma cobertura coluvial. O contato é marcado por uma zona de cisalhamento caracterizada por inúmeros planos estriados. A falha principal tem direção E-W, com plano mergulhando $53^{\circ}$ para norte e caráter transcorrente, aparentemente sinistral.

O corte representado pela Foto 10 , localizado a $500 \mathrm{~m}$ do precedente, mostra, da base para o topo: gnaisses, alúvios e, finalmente, colúvios. O contato gnaisses/alúvios é marcado por uma linha de pedras que permite analisar os deslocamentos gerados pelos vários ramos de um falha em flor negativa.

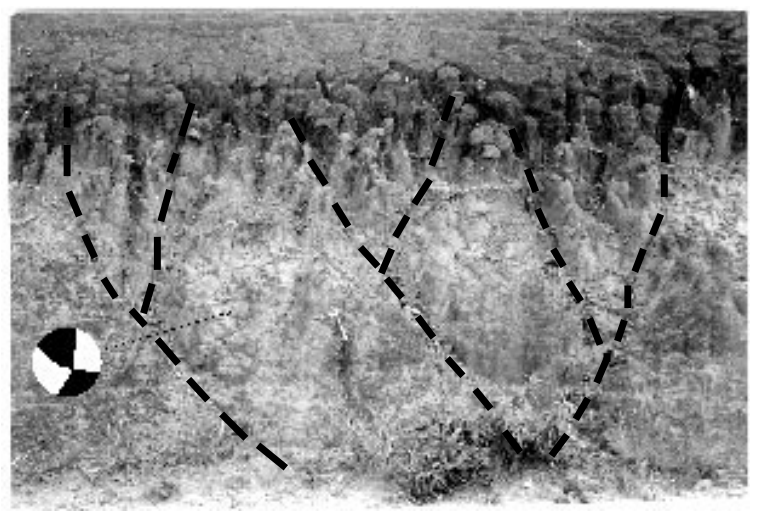

Foto 10: Falha em flor negativa afetando depósitos aluviais pleistocênicos, próximo do serro.

Photo 10: Flower structure affecting pleistocenic alluvial deposits, near Serro. 
Os campos de tensões foram obtidos pelo Método de Arthaud (1969), aplicado aos planos de falhas e respectivas estrias medidos nesses afloramentos. Eles apontam para um regime transpressivo, com direção média de encurtamento NW-SE e alongamento NNESSW. Resultado semelhante foi obtido com dados de um terceiro corte situado na mesma estrada, próximo à vila de Cachimbo (Saadi 1991, p.251).

Deve-se lembrar também os falhamentos recentes observados em várias partes da serra e de suas bordas, mas cuja análise não foi ainda sistematizada: reativação da transcorrência E-W que desloca a Serra do Cipó próximo a Cardeal Mota (Saadi 1991), falhamentos nas jazidas neogênicas de manganês da Serra do Cipó relatados por Dossin \& Dardenne (1984) e seus equivalentes encontrados na bacia do rio Pardo Grande (este trabalho), falhamentos afetando a Formação São Domingos de idade pliocênica, falhas pertencentes à "Descontinuidade Crustal Minas-Alagoas" afetando os terraços pleistocênicos do rio Araçuaí (Saadi 1994), entre outros.

\section{A evolução morfotectônica}

Ao fim deste trabalho, constata-se que a Serra do Espinhaço, em Minas Gerais, apresenta testemunhos de uma evolução geomorfológica transcorrida sob condições paleoclimáticas predominantemente úmidas e quentes. As fases de aridificação sugeridas por alguns autores não foram ainda sustentadas por nenhum argumento relevante, muito menos prova de qualquer ordem.

A ausência completa de depósitos mesozóicos sobre a serra parece indicar que esta constituía, já naquele período, uma saliência topográfica separando as bacias hidrográficas interiores das que vertiam para o litoral. Guimarães (1951) sustenta que esta configuração perdurava ainda no Plioceno. Isto explicaria a fossilização, e consequente preservação, de uma superfície mesozóica (Pós-Gondwana de King 1956) pelos arenitos cretácicos da Bacia Sanfranciscana - no Alto Paranaíba, a W da serra, e na parte subsidente (ou menos soerguida) do Cráton do São Francisco, a NW enquanto a mesma é de difícil comprovação na Serra do Espinhaço. Esta região devia, consequentemente, comportar-se como um primärrumpf, um sítio puramente erosivo com altitudes culminantes localizadas no Planalto de Diamantina.

Até o Plioceno, o desnível com relação ao nível do mar tinha sido grandemente atenuado, pois os sedimentos da Formação São Domingos mostram ser os equivalentes continentais dos do Grupo Barreiras litorâneo (nestas latitudes), com os quais ainda mantêm continuidade espacial ao longo do rio Pardo, no Sul da Bahia. É neste momento que o desenvolvimento da superfície fundamental (Sulamericana de King 1956), desencadeado por um soerguimento pós-cretácico, foi interrompido por um paroxismo tectônico que esboçou o quadro morfotectônico atual da serra e de suas margens (Fig. 10). Esforços compressivos reativaram as falhas de empurrão brasilianas, levantando escarpas a E e W do Cráton do São Francisco. Na Serra do Espinhaço, isto foi acompanhado pelo basculamento dos planaltos em direção E, e consequente incorporação de partes da drenagem sanfranciscana que avançava sobre a borda oeste. Isto é muito bem registrado no Planalto Setentrional, pela oscilação do divisor de drenagem entre as bacias dos rios Jequitinhonha e São Francisco. No Planalto de Diamantina, a estrutura antiformal regional registrada pelo contato embasamento impermeável/quartzitos proterozóicos porosos deve ter contribuido à manutenção de um divisor subterrâneo em posição mais oriental. Este, por sua vez, induziu a expansão das cabeceiras da drenagem sanfranciscana em direção E. A este processo contribuiram fortemente as zonas de cisalhamento que recortam o planalto em direção WNW-ESE a E-W. Fato semelhante ocorreu na borda oeste do Cráton do São Francisco, resultando na inversão morfotectônica da bacia sedimentar cretácica sanfranciscana, no Alto Paranaíba (Saadi 1991, 1993b).

Deve-se notar que a diferença de comportamento hidro-geomorfológico entre norte e sul se afirma a partir da Depressão de Couto de Magalhães, que separa os dois planaltos. A sua direção NW-SE é adaptada a falhas transcorrentes précambrianas, em cujos prolongamentos na bacia do rio Doce, Saadi (1991) demonstrou reativações pleistocênicas, com caráter de transcorrências sinistrais. A respeito desta depressão suspeita-se ainda a ocorrência de um fato hidrogeomorfológico da máxima importância, caso for futuramente confirmado por estudo específico: a associação entre a depressão, o rumo inicial de SE para NW do Alto Rio Jequitinhonha e as marcas de uma oscilação muito recente do divisor Jequitinhonha/São Francisco próximo a Bocaiúva (capturas do ribeirão de Areias e rio Tabatinga) sugerem que, antes do basculamento pliocênico, a drenagem desta região podia escoar para a bacia do rio São Francisco.

Voltando à atividade tectônica pliocênica, acreditase que, como consequência da movimentação das rampas de empurrão para $\mathrm{W}$, gerou-se duas consequências morfotectônicas de grande importância:

a - propagação da deformação na cobertura metassedimentar do Cráton do São Francisco (Grupo Bambuí), induzindo a drenagem do rio São Francisco a adotar o arqueamento para oeste conformemente ao arranjo estrutural regional (Fig. 10);

b - instalação de um contexto distensivo na borda oriental, expresso por abatimentos de blocos ao longo de falhas herdadas de direção NE-SW a N-S. Resultaram disso as depressões do Baixo Rio Araçuaí e Médio Rio Doce, bem como os basculamentos de blocos para W. O Graben de Virgem da Lapa é a melhor ilustração da distensão ocorrida na borda leste, com o preenchimento efetuado por $100 \mathrm{~m}$ de sedimentos lacustres e fluviais. Na bacia do Médio Rio Doce, os depósitos equivalentes foram representados por fluxos de lama depositados nas bordas falhadas dos blocos 
morfotectônicos definidos por Saadi (1991).

A continuidade da atividade tectônica durante o Pleistoceno é demonstrada de duas maneiras.

a - O profundo encaixamento dos vales nos planaltos e suas escarpas marginais, marcado por sistemas de terraços escalonados em alturas de até $300 \mathrm{~m}$, constitui uma resposta clara a um processo de soerguimento geral da plataforma brasileira.

b - Os falhamentos afetando depósitos aluviais e coluviais pleistocênicos, tanto em meio aos planaltos quanto nas áreas marginais, caracterizam uma tectônica compressiva expressa por movimentos predominantemente transcorrentes.

Esta interpretação encontra respaldo, também nos resultados de trabalhos realizados em várias áreas do Quadrilátero Ferrífero (Gorceix 1884, Brajnikov 1947, Saadi et al. 1992, Magalhães \& Saadi 1994, Marques et al. 1994, Sant-Ánna et al. 1994). Estes trabalhos demonstram que a atividade tectônica tem sido presente em todos os estados cronológicos da formação do relevo, alternando eventos compressivos e distensivos. A existência de tensões compressivas atuais foi confirmada pelo monitoramento da atividade sísmica que afetou recentemente a área marginal ocidental, nos arredores de Manga (Veloso et al. 1990). As causas desta sismicidade foram relacionadas à movimentação de uma falha inversa de direção N-S, com transporte de E para W. Isto confirma a possibilidade de reativação dos planos de empurrão herdados da Orogênese Brasiliana. Por outro lado, a repartição dos epicentros sísmicos conhecidos (Mioto 1984, 1993) está em conformidade com a organização morfotectônica proposta (Fig. 10)

\section{AGRADECIMENTOS}

Agradecimentos ao CNPq e à PrPq-UFMG, pelo suporte permanente às nossas atividades de pesquisa, através de bolsa e auxílios financeiros. Agradecimentos aos colegas Prof. Dr. P.A. Almeida Abreu, Prof. Msc. R.D. da Costa e Geóloga E.Caldeira Leite pela leitura crítica do texto e sugestões que o melhoraram muito.

\section{REFERÊNCIAS BIBLIOGRÁFICAS}

ABREU, A.A. de 1982. Análise geomorfológica: reflexão e aplicação (Uma contribuição ao conhecimento das formas de relevo do Planalto de Diamantina-MG). São Paulo-SP, USP, Tese de Livre Docência, 296 p.

ALMEIDA ABREU, P.A. \& PFLUG, R. 1994. The geodynamic evolution of the southern Serra do Espinhaço, Minas Gerais, Brazil. Zbl. Geol. Paläont., Teil I, H. 1/2: 21-44.

ALMEIDA ABREU, P.A.; PFLUG, R. \& SCHORSCHER, H.D. 1992. Cover/basement relationships in the southern Serra do Espinhaço, Minas Gerais, Brazil. Zbl. Geol. Paläont., Teil I, H. 6: $1749-1760$.

ARTHAUD, F. 1969. Méthode de détermination graphique des directions de raccourcissement, $\mathrm{d}$ ' allongement et intermédiaire d' une population de failles. Bull. Soc. Géol. France, 7(11):729737.

AUGUSTIN, C.H.R.R. 1994. Amphitheaters and hollows with depositional sequences and their significance on the evolution of tropical landscape. In: INT. SEDIM. CONG., 14, Recife-
PE, 1994. Proceedings..., Recife, 1994. pp.G5-G6.

AUGUSTIN, C.H.R.R; VALADÃO, R.C. \& SANCHES, H.M. 1994. Processos evolutivos da borda da Serra do Cabral (MG): evidências geomorfológicas e pedológicas. In: CONG. BRAS. GEOL., 38, Camboriu-SC, 1994. Anais ..., SBG, 1994. (3):202204.

AUGUSTIN, C.H.R.R.; VALADÃO, R.C. \& FOGAÇA, A.C.C. 1994. Gênese das coberturas superficiais vermelho-amarelas sobre o Grupo Macaúbas (Espinhaço Meridional /MG). In: CONG. BRAS. GEOL., 38, Camboriu-SC, 1994. Anais..., SBG, 1994. (3):276-278.

BARBOSA, G.V. 1960. Reconhecimento geomorfológico. In: Estudo geográfico do Vale do Médio Jequitinhonha, Belo Horizonte, Imprensa Oficial, seção 01; p. 18-48.

BARBOSA, G.V. 1966. O significado da estrutura geológica para o mapeamento geomorfológico de Minas Gerais. Bol. Mineiro de Geog., Belo Horizonte-MG, (12):37-58.

BARBOSA, G.V.; KOHLER, H.C.; NASCIMENTO, N.R. do \& CASTRO, V.H.C. 1980. Depósitos cenozóicos de Virgem da Lapa, MG. IGC-IFMG, Belo Horizonte-MG, 12 p.

BARBOSA, G.V. \& KOHLER, H.C. 1981. O sistema lagunar do Parque Estadual do Rio Doce (MG). Bol SBG-MG, (2):37-46.

BRAJNIKOV, B. 1947. Essai sur la tectonique de la région à l' est de Belo Horizonte, Minas Gerais, Brésil. Bull. Soc. Géol. de France, 5(17):321-335.

CETEC/MG 1980. Diagnóstico da Situação Ambiental do Vale do Jequitinhonha. In: Projeto Estudos Integrados do Vale do Jequitinhonha - Belo Horizonte-MG, 1980.

COSTA, R.D. da 1994. Análise estatística de fotolineações: um exemplo no Espinhaço Meridional. In: CONG. BRAS. GEOL., 38, Camboriú-SC, 1994. Anais..., SBG, 1994. (2):241-242.

DOSSIN, I.A. \& DARDENNE, M.A. 1984. Os depósitos supergênicos de manganês da borda ocidental da Serra do Cipó, MG (Quadrícula Inhame). In: CONG. BRAS. GEOL., 33, Rio de Janeiro, 1984. Anais..., SBG, 1984. (3):1129-1143.

FREYBERG, B. von 1932. Ergebnisse geologischer Forschungen in Minas Geraes (Brasilien). N. Jahrbuch für Mineralogie, Geologie und Paläontologie, Sonderband II, Stuttgart, 453 p.

FREITAS, R.O. 1951. Ensaio sobre a tectônica moderna do Brasil. FFCL/USP, Bol.130, Série Geol.,(6):1-120.

GORCEIX, H. 1884. Bacias terciárias d'água doce nos arredores de Ouro Preto (Gandarela \& Fonseca), Minas Gerais, Brasil. Anais Esc. Min. Ouro Preto, (3):75-92.

GUIMARÃES, D. 1951. Arqui-Brasil e sua evolução geológica. Bol. D.F.P.M./DNPM, Rio de Janeiro, (88):1-341.

HARTT, C.F. 1870. Geology and physical geography of Brazil. Fields Esgood \& Co., Boston-USA, 620p.

IGA 1978. Mapa Geomorfológico do Projeto RADAR-MG, 1:500.000. SECT/IGA, Belo Horizonte-MG.

KING, L.C. 1956. Geomorfologia do Brasil Oriental. Rev. Bras. Geog., 18(2):1-147.

KUX, H.J.H. 1976. Geologische, geomorphologische und sedimentologische Untersuchungen bei Diamantina in der südlichen Serra do Espinhaço. Freiburg im Breisgau, Alemanha, Tese de doutorado.

MACHADO, A.F.; QUINTÃO, N.H. \& MUZZI MAGALHÃES, P. 1986. Geologia da porção centro-sul da Quadrícula de Ouro Fino-Conceição do Mato Dentro/MG. IGC/UFMG-CGE, dezembro de 1986, Belo Horizonte. Trabalho Geológico de Graduação, 80 p.

MAGALHÂES Jr., A. \& SAADI, A. 1994. Ritmos da dinâmica fluvial controlados por soerguimento regional e tectônica de falhamento: o vale do rio das Velhas na região de Belo Horizonte-MG. Geonomos, Belo Horizonte-MG, 2(1):42-54.

MARQUES, M. R.; MOREIRA, P. \& SAADI, A. 1994. Evolução morfodinâmica da borda norte do Quadrilátero Ferrífero, com base na dinâmica fluvial pleistocênica do rio Paraopeba. In: SIMP. GEOG. FÍS. APLIC., 4, São Paulo, 1993. Anais..., IG/ USP, 1994. p.49-54.

MEIS, M.R.M de 1978. Estratigrafia preliminar para a sequiência de colmatagem dos lagos neoquaternários do Médio Vale do Rio Doce. Anais Acad. Bras. Ciências, 50(1):126-127.

MIOTO, G.J.A. 1984. Mapa de risco sísmico do Sudeste Brasileiro. São Paulo, IPT, Monografia 10, Publ. 1563.

MIOTO, G.J.A. 1993. Sismicidade e zonas sismogênicas do Brasil. 
Rio Claro-SP, UNESP, Tese de doutoramento. 2 vol., 558 p.

OLIVEIRA, F.V.C. \& ALKMIM, F.F. 1994. Estilo estrutural e curvatura da porção sul do front do Espinhaço. In: CONG. BRAS. GEOL., 38, Camboriu-SC, 1994. Anais..., SBG, 1994. (2):259-260

PEDROSA-SOARES 1981. A geologia da Folha de Virgem da Lapa, Minas Gerais. IGC/UFMG, Relatório Final de Bolsa de Aperfeiçoamento-CNPq, 52p.

PEDROSA-SOARES, A.C. \& SAADI, A. 1989. O segmento meridional da Falha de Taiobeiras, MG. In: SIMP. GEOL. MG, 5, Belo Horizonte, 1989. Anais..., SBG-MG, 1989, Bol. SBG$M G,(10): 161-165$.

PEDROSA-SOARES, A.C.; NOCE, C.M.; VIDAL, P.; MONTEIRO, R.L.B.P. \& LEONARDOS, O.H. 1992. Toward a new tectonic model for the Late Proterozoic Araçuaí (SE Brazil) - West Congolian (SW Africa) belts. J. South Amer. Earth Sci., 6:33-47.

PENCK, W. 1924. Morphological analysis of landforms. English translation by H. Czech and K. C. Boswell, London, 1953.

PFLUG, R. 1969. Das Überschüttungsrelief des Rio Doce Brasiliens. Zeit. f. Geomorph., 13:141-162.

PFLUG, R. \& RENGER, F. 1973. Estratigrafia e evolução geológica da margem SE do Cráton Sanfranciscano. In: CONG. BRAS. GEOL., 27, Aracajú-SE,1973. Anais..., SBG, 1973, (1):5-19.

RENNÓ, C.V. 1974. Uso de imagens de radar no mapeamento de superfícies de aplainamento: um exemplo do nordeste de Minas Gerais. In: CONG. BRAS. GEÓG., Belém-PA, 1974. Anais..., AGB/FIBGE, 1974. p.I.32-I.37.

ROLIM, V.K. 1992. Uma interpretação das estruturas tectônicas do Supergrupo Espinhaço, baseada na geometria dos falhamentos de empurrão. Rev. Esc. de Minas, Ouro Preto-MG, 45(1 e 2):75-77.

SAADI, A. 1991. Ensaio sobre a morfotectônica de Minas Gerais. Belo Horizonte-MG, IGC/UFMG, Tese para admissão a cargo de Professor Titular, maio de 1991, $300 \mathrm{p}$.

SAADI, A. 1993a. Neotectônica da Plataforma Brasileira : esboço e interpretação preliminares. Geonomos, Belo Horizonte-MG, 1(1):1-15.

SAADI, A. 1993b. Neotectônica e tectônica recorrente na Porção Sul do Craton do São Francisco. In: SIMPÓSIO DO CRATON DO SÃO FRANCISCO, 2, Salvador-BA, 1993. Anais..., SBG/ BA, 1993. p. 230-232.

SAADI, A. 1994. A Descontinuidade Crustal Minas-Alagoas (DCMA): uma faixa rúptil ativa durante o Cenozóico. In: CONGRESSO BRASILEIRO DE GEOLOGIA, 38, CamboriúSC, 1994. Anais..., SBG, 1994. (2):256-257.

SAADI, A. \& VALADÃO, R.C. 1987a. O cenozóico da porção mediana-central do Espinhaço Meridional, primeira síntese. In: CONG. DA ABEQUA, 1, Porto Alegre-RS, 1987. Anais..., ABEQUA/UFRGS, 1987. p. 393-407.
SAADI,A. \& VALADÃO, R.C. 1987b. Evolução geomorfológica quaternária da região de Gouveia, Serra do Espinhaço. In:SIMP. GEOL. MG, 4, Belo Horizonte-MG, 1987. Anais..., SBG/MG, 1987. Bol. SBG-MG, (7):434-448.

SAADI, A.; MAGALHÃES Jr., A.P. \& MARQUES, M.R. 1991. UHE IRAPÉ, Etapa 1-Estudos de viabilidade: Meio ambienteGeomorfologia-Relatório Final. ENERCONSULT/CEMIG, VIR-3473, Novembro de 1991.

SAADI, A. \& PEDROSA-SOARES, A.C. 1991. Um graben cenozóico no Médio Jequitinhonha, Minas Gerais. In: WORKSHOP S/ NEOTECTÔ. E SEDIM. CONT. CENOZ. NO SE BRAS., 1, Belo Horizonte , 1991. Anais.... SBG-MG/ CEMIG, 1992. Bol. SBG-MG, (11):101-124.

SAADI, A.; SGARBI, G.N.C. \& ROSIERE, C.A. 1992. A Bacia do Gongo Soco; nova bacia terciária no Quadrilátero Ferrífero: controle cárstico e/ou tectônico. In: CONG. BRAS. GEOL., 37, São Paulo, 1992. Anais..., SBG, 1992. (1):600-601.

SANT-ÁNNA, L.G.; SCHORSCHER, J.H.D. \& RICCOMINI, C 1994. Tectônica cenozóica no extremo leste do Quadrilátero Ferrífero, Minas Gerais, Brasil. In: CONG. BRAS. GEOL., 38, Camboriu-SC, 1994. Anais.... SBG, 1994. (1):575-576.

SOUZA, C.J.de O. \& SAADI, A. 1994. Contribuição à geomorfologia da bacia do rio Doce. In: SIMP. GEOG. FÍS. APLIC., 4, São Paulo-SP, 1993. Anais..., IG/USP, 1994. p.157161

TRIFONOV, V.G. 1989. An overview on neotectonic studies. Intern Geol. Review 31: 111-160.

TURCQ, B.; SUGUIO, K.; SOUBIÈS, F.; SERVANT, M. \& PRESSINOTI, M.M.N. 1987. Alguns terraços fluviais do sudeste e centro-oeste brasileiro datados por radiocarbono: possíveis significados paleoclimáticos. In: CONG. DA ABEQUA, 1, Porto Alegre, 1987. Anais..., ABEQUA/UFRGS, 1987. P. 379-392.

TURCQ, B.; SUGUIO, K.; ALBUQUERQUE, A.L.S.; COCQUIT, C.; KOHLER, C.H.; MARTIN,L. \& SALGADOLABOURIAU, M.L. 1994. Evolution of lakes in the Middle Doce River Basin, Minas Gerais, Brazil. In: INT. SEDIM. CONG., 14, Recife-PE, 1994. Proceedings..., 1994. p.G5-G6.

VALADÃO, R.C.; AUGUSTIN, C.H.R.R.; RICARDO, L. \& CANÇADO, F.L.L. 1994. Conglomerados cretácicos na porção leste da Serra do Cabral (MG): novos subsídios à reconstrução paleogeográfica mesozóica. In: CONG. BRAS. GEOL., 38, Camboriu-SC, 1994. Anais..., SBG, 1994. (3):237-239.

VELOSO, J.A.; ASSUMPÇÃO, M.; CARVALHO, J.; BARBOSA, J.R.; FONTENELE, D.; BASSINE, A.; GOMES, I.P.; BLUM, M. \& RIBEIRO, R.K. 1990. Sismicidade recente nos estados de Minas Gerais e Bahia. In: WORKSHOP S/ NEOTECTÔ. E SEDIM. CONT. CENOZ. NO SE BRAS., 1, Belo Horizonte, 1990. Anais..., SBG-MG, 1992. Bol. SBG-MG, (11):57-61. 
